\title{
WHAT IF ALEXANDER HAMILTON \\ HAD BEEN ARGENTINEAN? \\ A COMPARISON OF THE EARLY MONETARY \\ EXPERIENCES OF ARGENTINA \\ AND THE UNITED STATES
}

\author{
Michael Bordo \\ Carlos A. Végh \\ Working Paper 6862 \\ http://www.nber.org/papers/w6862
NATIONAL BUREAU OF ECONOMIC RESEARCH
1050 Massachusetts Avenue
Cambridge, MA 02138
December 1998

The authors are grateful to Jim Conklin, Michael Edelstein, Stanley Engerman, Jeffry Frieden, Herschel Grossman, Adam Klug, Georg Rich, Angela Redish, Anna Schwartz, Eugene White, and seminar participants at Ben-Gurion University, Columbia University, University of Texas, TelAviv University, Rutgers University, Brescia Seminar on Monetary History, Harvard University Latin Seminar, and NBER Summer Institute for helpful comments and suggestions. The views expressed here are those of the author and do not reflect those of the National Bureau of Economic Research.

- 1998 by Michael D. Bordo and Carlos A. Végh. All rights reserved. Short sections of text, not to exceed two paragraphs, may be quoted without explicit permission provided that full credit, including ${ }^{\circledR}$ notice, is given to the source. 
What if Alexander Hamilton Had Been Argentinean?

A Comparison of the Early Monetary Experiences

of Argentina and the United States

Michael D. Bordo and Carlos A. Végh

NBER Working Paper No. 6862

December 1998

JEL No. F41, N16, N26

\section{ABSTRACT}

The contrast between the early nineteenth century Argentinean experience of high inflation and the American experience of low inflation is interpreted in terms of a dynamic monetary model of optimal taxation. It is argued that the two countries' experiences diverged because of the different constraints they faced in financing wartime government expenditures. In the presence of frequent wars, ever-tightening access to foreign capital, and an inadequate tax base, Argentina's use of the inflation tax may be viewed as an optimal solution to its wartime problems. By contrast, with the exception of the Revolutionary War, the absence of such constraints in the United States required full-tax smoothing, with only a temporary use of the inflation tax during wartime. Such policies were embodied in Alexander Hamilton's fiscal package of 1790, which allowed the United States to bond-finance most subsequent wartime expenditures.

Michael D. Bordo

Department of Economics

Rutgers University

New Brunswick, NJ 08901

and NBER

bordo@eonomics.rutgers.edu
Carlos A. Végh

Department of Economics

UCLA

Los Angeles, CA 90095

and NBER

cvegh@ucla.edu 


\section{Introduction}

No hay más que una esperanza de que el papel-moneda de Estado, una vez establecido y convertido en hábito, desaparezca, y es la de que arruine y entierre al gobierno que lo ha creado, por su propia virtud de empobrecimento y de ruina. Entonces se verá producirse este fenómeno, que no es sino muy concebible y natural: que el gobierno que necesitó crear el papel moneda para existir, tendrá que suprimirlo para conservar su existencia. ${ }^{1}$

Juan Bautista Alberdi (1810-1884) ${ }^{2}$

As the prophetic introductory quote suggests, Alberdi saw it as a distinct possibility that a government would have to eliminate de facto the national currency to preserve its own existence. In this light, the highly successful 1991 Argentinean Convertibility Plan, which basically established a currency board, is perhaps the ultimate tribute to Alberdi's deep- rooted distrust of inconvertible paper-money: after hyperinflation threatened to destroy the social fabric of the country, the Argentinean government had little choice but to destroy the monster - for inconvertible paper-money was no less than that in Alberdi's mind - that it had created roughly 170 years before.

Up until the 1991 Convertibility plan, Argentina provided a consummate example of a chronic inflation country. In the twentieth century, it experienced chronic inflation since the early 1950s in spite of repeated stabilization attempts. Argentina's stormy relationship with inflation, however, goes back to the early nineteenth century, as Alberdi's virulent attacks on paper-money and ensuing inflation vividly illustrate. Indeed, the first long period of high inflation (in what would later officially become Argentina) goes from the mid 1820 s - roughly a decade and half after the 1810 Revolution from Spain - to the early 1860s. Even in the following 80 years, when inflation on average was not exceptionally high, there were a number of inflationary episodes and successful adherence to convertibility rules was rare. Thus, taking a long sweep of history from 1810 to 1990 suggests that the experience of the first half of the twentieth century when the average inflation rate was relatively low - is an aberration from a more permanent pattern of high and chronic inflation, which may have been finally broken by the quasi-currency board established by the Convertibility Plan.

Argentina's long inflationary history stands in sharp contrast to the tradition of price stability of a country such as the United States which, in spite

1 "There is only one way in which the State-issued paper-money - once it has been established and become a habit -... will disappear, and that is that it ruins and buries the State that created it, by virtue of its own capacity for impoverishing and ruining. Then the following phenomenon will take place, which is only very conceivable and natural: the government that needed to create the paper-money to exist will have to suppress it to preserve its own existence." (Authors' translation.)

${ }^{2}$ Alberdi was one of the most influential political and economic thinkers of nineteenth century Argentina. The above quote, reproduced in Alberdi (1989, p. 162), belongs to a manuscript on an economic interpretation of Argentina's political history published after his death. (See Végh Villegas (1989) for an analysis of Alberdi's economic thinking.) 
of initiating its independent life under broadly similar circumstances, followed quite a different path in this respect. In effect, although the United States had episodes of high inflation associated with wartime emergencies, the record suggests a pattern of price stability up until the 1960s, and relatively low inflation by international standards since then. The dramatic contrast between the inflationary history of both countries raises some very important questions regarding the origin of inflation and the circumstances which may lead countries to resort to inflationary finance.

As reflected in the introductory quote, Alberdi provided a clear hypothesis for the origin and propagation of high inflation in Argentina. Inflation would be the inevitable consequence of creating paper-money and would tend to perpetuate itself unless a hard-money standard was restored. This paper tackles the same question but offers a somewhat different explanation. In our view, long processes of high inflation may reflect the optimal response to specific circumstances. Thus, unlike Alberdi, we do not believe-nor does the evidence bear it out-that the mere existence of paper-money is sufficient to put the inflationary process in motion. To identify the circumstances that may have led Argentina to rely on high inflation, we develop a dynamic public finance model.

As a study in contrast, the paper also examines the early monetary history of the United States - a country which had many similar characteristics to Argentina. Both countries were new-world republics in resource-rich, land-intensive, temperate-zones regions with great potential for development. The contrast between the highly dissimilar inflation paths of Argentina and the United States proves quite helpful in identifying the key underlying factors.

The examination for Argentina reveals that the early experience of chronic inflation can be traced to the presence of several constraints on the government's financing capability: (i) a series of external wars interposed onto a continuous civil war; (ii) an unstable fiscal regime linked primarily to an inefficient tax base; (iii) long-term bond financing becoming less and less feasible over time. In light of these constraints, successive banks of issue were forced to depart from their original intent of preserving convertibility and became engines of inflation. An additional aggravating factor - which we do not formally analyze - may have been the existence of political forces that benefitted from inflation and were thus opposed to measures which would have allowed the government to rely on non-inflationary financing.

By contrast, after a notorious episode of extremely rapid inflation during the War of Independence, the United States developed a set of fiscal and monetary institutions - under the brilliant tutelage of Alexander Hamilton - which would ensure price stability in peacetime conditions but also allow governments to have adequate access to seigniorage and long-term bond finance in wartime emergencies. Once the emergency passed, both paper note issue and debt would be retired in concordance with a model of optimal tax smoothing.

To interpret the evidence, the paper develops a dynamic, monetary model of public finance, in the tradition of Phelps (1973) and Lucas and Stokey (1983). The optimality of using the inflation tax derives from the fact that collecting conventional taxes is costly, along the lines of Végh (1989). Strong assumptions 
on preferences allow us to derive sharp tax-smoothing results, in the spirit of Barro (1979). When collection costs are positive, the inflation tax is also fully smoothed out. Hence, to rationalize the use of higher inflation during wartime, we incorporate into the analysis two salient features of the Argentine experience. First, we assume that collection costs are higher during wartime, reflecting the wartime blockades which had a devastating effect on trade taxes. Second, we assume that the costs of borrowing in international capital markets are an increasing function of borrowing needs. We show that in both cases it is optimal to raise the inflation tax during wars.

The paper proceeds as follows. Section 2 examines the monetary and financial history of Argentina from 1810 - when independence from Spain was declared - to 1867 , which marks the beginning of a period of relative economic stability, after the national reunification achieved in 1862. Section 3 focuses on the monetary and financial history of the United States from the revolution to the resumption of specie payments after the Civil War in 1878. This period of nation-building is in many ways comparable to the period 1810-1867 in Argentina's history.

Building on the factors revealed by the historical comparison, Sections 4 and 5 present the public finance model that captures many of the salient features of Argentina's inflation experience (wartime shocks, high collection costs of conventional revenues, imperfect access to international capital markets, and inflation persistence) and that of the United States (tax smoothing, positive collection costs, and inflation reversion). Section 6 interprets the Argentinean and United States evidence in terms of the model and identifies the factors that may have given rise to some of the constraints on fiscal policy incorporated in the model. Section 7 presents concluding remarks.

\section{Early Argentinean experience: 1810-1867}

\subsection{Political background}

During the sixteenth and seventeenth centuries, the development of Spanish America was dominated by the quest for precious metals and native Indians. Since the River Plate territories had neither in any abundance, they remained largely a remote, ignored outpost of the Viceroyalty of Peru. ${ }^{3}$ The fortune of the River Plate territories began to change during the eighteenth century, when the commercial revolution brought about a large increase in transatlantic trade which greatly benefitted the city and port of Buenos Aires. In 1776, the Argentinean territories were given autonomous status as the Viceroyalty of the Rio de la Plata. The capital, Buenos Aires, flourished under the system of "free and protected" trade between Spain and its colonies, which disintegrated during the French Revolutionary and Napoleonic Wars. Warfare abroad and the conflicts between monopolists and free traders eventually led to the May 25, 1810

\footnotetext{
${ }^{3}$ On the political history of Argentina, see Rock (1987). For an economic history, sce Alemann (1989).
} 
Revolution, centered in Buenos Aires. Although the Revolution was welcome in most regions of the Viceroyalty, Cordoba, Montevideo, Asuncion, and the Alto Peru did not recognize the new authorities established in Buenos Aires and remained loyal to Spain. ${ }^{4}$ The ensuing wars of independence took place over the following 10 years. By 1820, the revolution from Spain had essentially been completed, although the territories of Alto Peru (with the Potosi mines) and Asuncion had been lost, and would become the independent republics of Bolivia and Paraguay, respectively. ${ }^{5}$

Shortly after the May 1810 Revolution, the differences between Buenos Aires (the so-called "unitarios" who wanted a strong central authority based in Buenos Aires) and the rest of the territories (the so-called "federales," who wanted provincial autonomy) grew. The conflict between "unitarios" and "federales" quickly turned into bloody civil wars which, with occasional truces, would remain a permanent feature of Argentina's political landscape for around 50 years after the Revolution. National unity was only achieved in 1862, after Mitre became the first elected president of what officially became known as the Argentinean Republic.

\subsection{Monetary conditions during the colonial period}

During the Colonial period, there was no paper money circulating. As a result, monetary conditions were largely determined by silver production in the mines of Potosi. ${ }^{6}$ The tradeable goods produced in Argentinean territories - raw cotton, cereals, cattle, sheep, horses and mules, and wool - were mostly marketed in Alto Peru in return for silver. Silver would then be used to buy imported manufactured goods, such as weapons, tools, and European clothing. Until the late eighteenth century, however, the Spanish Crown normally required that imports be acquired by way of Lima (Peru) rather than by way of Buenos Aires. ${ }^{7}$ The Spanish Crown feared that (i) non-Spanish goods would invade its territories,(ii) silver being exported through Buenos Aires would go untaxed, and (iii) silver would fall into the hands of Spain's European enemies through Portugal.

Given that goods brought into Buenos Aires through the Atlantic (mainly by the Portuguese) were much cheaper due to the shorter route, contraband flourished during the Colonial Period. As trade with the Portuguese increased, much of the silver obtained from trade with Potosi found its way to Buenos Aires, instead of flowing back to Lima as the Spanish wanted it. The flow of silver from Potosi to Buenos Aires was never totally controlled, in spite of very tough measures such as the establishment of internal customs in Cordoba in 1622 (the so-called "Aduana Seca" for "dry customs").

\footnotetext{
${ }^{4}$ Local revolts, however, soon took place which were as antagonistic to Spain as to Buenos Aires' authority.

${ }^{5}$ In 1828, the East Bank territories (whose capital was Montevideo) would also become an independent republic (Uruguay).

${ }^{6}$ Actually, the name "Argentina" derives from the Latin version of silver.

${ }^{7}$ Goods would be sent from Spain to the Isthmus of Panama, then on to Lima, and then transported overland to consumers in the far South.
} 


\subsection{Debt and quasi-monies: Financing the wars of inde- pendence, 1810-1821.}

According to Hansen (1916), the Revolution from Spain was perhaps one of the few great emancipatory processes that took place without recourse to paper money. ${ }^{8}$ In fact, Difrieri (1967, p. 23) reports that during 1811 and 1812 government revenues exceeded expenditures, partly because of a special tax ("contribucion extraordinaria") of 630.038 pesos decreed in May $1812 .{ }^{9}$ By 1813 , however, the constant expansion of military expenditures and a drop in trade revenues - as a result of a Spanish blockade of the Rio de la Plata - led the Buenos Aires authorities to issue the first compulsory loan. ${ }^{10}$ All in all, during the period 1813-1821, compulsory loans amounted to 2.96 million pesos.

A key feature of the period 1810-1821 seems to be the increasing degree of "moneyness" acquired by government debt. Already the first compulsory loan issued in 1813 stipulated that, after two months, the interest-bearing treasury bills (called "vales de aduana" for "customs bills") would be received as custom payments and, after six months, the Treasury would accept them in payments (Difrieri (1967), p. 27). Furthermore, these treasury bills could be traded, and later were issued "al portador" (bearer bonds). The second compulsory loan of September 1813 did not even set an interest rate. A further de-facto monetization of the government debt occurred in March 1817, when it was decreed that all credit against the government, whatever its nature or origin, could be used for custom payments (Difrieri (1967), p. 35). ${ }^{11}$ Finally, in 1819 and 1820 the government issued small-denomination notes to be used by customs (with restrictions on the amount that could be given to any particular individual) and to pay military and public wages. By then, the difference between public debt and money had all but disappeared.

As expected, the abundance of quasi-monies implied that government paper circulated at a big discount in terms of (hard) money (70 percent in 1818). This led to a great deal of speculation as some holders of government debt had little choice but to sell it to importers at a large discount, who would then use it to pay custom duties. In 1818, the "Caja Nacional de Fondos de SudAmerica" was created (a sinking fund), following the French examples of 1722 and 1749 , whose main purpose was to receive deposits from the public which would then be used to amortize the public debt. The "Caja" failed to attract any large amounts of (hard) money mainly because it was not profitable to do so since the government paper could be deposited at its face value. In addition, and although in principle it was strictly prohibited from doing so, the "Caja" transferred some of its funds to the government during 1820 (Difrieri (1967), p.

\footnotetext{
${ }^{8}$ Indeed, Hansen (1916) sees this feature as a key difference between the Argentinean and American independence wars.

${ }^{9}$ Hansen $(1916$, p. 116$)$ reports that in the first twelve months following the May 25,1810 Revolution, total revenues were 4.7 million pesos and total expenditures were 4.2 million pesos.

10 A detailed account of all compulsory loans during the period 1813-1821 can be found in Hansen (1916, p. 173).

${ }^{11} \mathrm{Ty}$ pically, the government would establish that some fraction of the custom duties should be paid in cash (hard money) and the rest with govermment paper.
} 


\subsection{Financial and fiscal reforms, 1821-1825 ${ }^{12}$}

By 1821, 10 years of foreign and civil wars had left a legacy of financial and fiscal confusion. The Rodriguez administration (1821-1824), mainly under the leadership of Rivadavia, decided it was time to carry out a financial and fiscal reform. The main fiscal reforms consisted in introducing the practice of budgeting revenues and expenditures on a yearly basis and abolishing many minor and inefficient taxes and various extraordinary contributions imposed in the previous decade.

By far, the most important source of revenue for the province was custom duties, which provided more than 80 percent of total revenues (Table 1). The provincial finances were thus highly vulnerable to the fluctuating fortunes of foreign and interprovincial commerce. Although the authorities were well aware that such dependency was a constant threat to the financial stability of the province, there was little else they could do. Trade taxes were easy to collect and faced little resistance from the population. The introduction of a capital tax (the "contribucion directa") in 1821 failed to account for any important share of revenues. In 1829 , this tax produced only three percent of total tax revenues.

On the financial front, the first task of the Rodriguez administration was to form a commission to ascertain the amount owed by the Treasury. The public indebtedness consisted of treasury bills issued in anticipation of revenues, obligations arising out of forced loans, bonds of the "Caja Nacional," and other claims. The commission estimated the total public indebtedness to be about 2 million pesos, most of which consisted of negotiable bills. The government was forced to re-issue the bills that it received in payments of custom duties and other taxes. Hence, the only solution to the problem was to consolidate the total debt and convert it into long term debt. The funding operation was carried out on the basis of a November 1821 decree, which authorized the government to issue bonds of 5 million pesos. Further bond issues in 1823 and 1824 were necessary to complete the operation. By the end of the funding operation in 1824, 6.4 millions worth of bonds had been issued (Table 1).

As part of the financial reforms, and as early as 1821, the government encouraged the establishment of a discount bank. Thus, in 1822, the Legislative Assembly granted a private company the exclusive right to establish one. The bank, officially known as Banco de Buenos Aires, began operations in September 1822. In addition to engaging in discounting operations, accepting deposits, and acting as the agent of the provincial Treasury, the bank could issue notes that would be redeemable in gold on demand.

The government hoped to accomplish two things by having a discount bank. First, it was expected that the bank would be able to mobilize a substantial amount of specie and thus provide the basis for a sound currency. Second,

\footnotetext{
${ }^{12}$ The main reference for the period 1821-1852 is Burgin (1946).
} 
currency expansion together with a liberal discount policy was supposed to ease credit conditions, which were considered tight. However, neither of these two objectives were fulfilled. The bank failed to attract any considerable amount of specie and, although it was fully capitalized, nearly half of the bank shares were paid for with its own funds. Over the period 1823 to 1826 the bank pursued a liberal discount policy, extending many loans for "speculative purposes of purely financial operations" (Burgin, p. 59) so that by the end of 1826, the note issue was such that the reserve ratio was less than 10 percent. In January 1826, and fearing a loss of reserves, the bank asked for and was granted a suspension of convertibility.

The Banco de Buenos Aires was succeeded by the Banco Nacional. It was designed as a public bank to serve as the government's fiscal agency, to discount notes issued by the Treasury, and to open a credit of 2 million pesos in favor of the government (Burgin, p. 61). Thirty percent of its initial capital was taken over from the Banco de Buenos Aires and the rest, except for a minor sum in specie, was in Treasury bills. Although in its charter, notes were to be convertible, in actual fact this was never the case and within two years the redemption clause was repealed and the government took over the bank's specie holdings.

\subsection{The war with Brazil, 1825-1828}

The war with Brazil, which began in 1825 , was a key event in the early history of the province of Buenos Aires. ${ }^{13}$ During the siege of Montevideo by Lavalleja and the Buenos Aires army, Brazil's strong navy imposed a highly successful naval blockade on Buenos Aires, which had a devastating effect on trade taxes. Trade in 1827 , for example, was only one third of what it was in 1824. As a result, during 1825-1828 trade taxes accounted for only 20 percent of total revenues compared to 80 percent at the beginning of the decade. Maintaining an army of 20,000 men, combined with the devastating effects of the naval blockade, made this war much more costly than the wars of Independence (Rock, 1987).

The fiscal effects of the war with Brazil are apparent from Table 1 and Figure 4, which show large deficits for four consecutive years (1825-1828). ${ }^{14}$ To finance the war, and given that the interest rate charged by the Banco Nacional was considerably below the open market rate, the Buenos Aires government relied heavily on credit from the Banco Nacional. However, since the credit resources of

\footnotetext{
${ }^{13}$ In 1822, Brazil had declared its independence from Portugal and annexed the Banda Oriental, which used to be part of the Viceroy of the Rio de la Plata and had been taken over by Brazil two year before. In 1825, after a small group of "orientales" exiled in Buenos Aires successfully besicged Montevideo after landing in Colonia and obtaining local support, Brazil declared war on the Provincias Unidas.

${ }^{14}$ Note from Table 1 that for the period 1825-1828 the amount of loug term bond issues amounted to 6.26 million, while net note issue was 10.7 million (= $12.41-1.68)$. Assuming that the deficit was fully financed by long term bonds and note issues, this implies that the total deficit during this period was in the order of 17 million (an average of roughly 4 million per year). Note also that roughly 63 percent of the wartime deficit (i.e., $10.7 / 17$ ) was money-financed, while the remaining 37 percent was debt-financed.
} 
the Banco Nacional were far short of the government's borrowing requirements, the Banco Nacional had to print money to meet the Treasury's requests. Thus, during the same period (1826-1830), total money issue increased by a factor of 7.9 (Table 1 and Figure 3). The ensuing inflationary process began in February 1826 and continued almost uninterruptedly until mid-1830, with the exchange rate depreciating by a factor of 7.3 from January 1826 to May 1830 (Figure 1 ). At the beginning of 1830 , long term government bonds were selling at an average discount of 40 percent (Burgin (1946), Table 32, p. 175).

\subsection{Failed stabilization attempts}

In the aftermath of the war with Brazil, the province of Buenos Aires was once again headed toward bankruptcy. The financial and fiscal problems were reminiscent of those prevalent in 1821 - immediately after the wars of Independence. These problems, which had never been resolved, were considerably aggravated by the war with Brazil. The situation was particularly worse in one very important respect: monetary and price instability had been added to the picture.

Although the inflationary process that began in 1826 would take a respite for six years, three underlying factors would ensure that monetary instability would never quite disappear for the next 40 years, and would always be ready to return with a vengeance. First, the Treasury continued to depend on trade taxes for most of its revenues. Second, long-term bond-financing was becoming more and more difficult as the public became increasingly reticent to buy additional public debt and because a London loan for 5 million gold pesos contracted in 1824 was defaulted on in 1827, and servicing was not permanently restored until $1849 .{ }^{15}$ Third - and this is a new element that emerged only after $1826-$ inflation began to benefit some of the most powerful economic groups: the "hacendados (cattle-ranchers) and the "saladeristas" (meat exporters). Specifically, the inflationary process had led to a substantial increase in the relative price of traded goods (a real exchange rate depreciation), as export prices matched the exchange rate depreciation but wages and prices of home goods lagged behind. These economic groups were thus opposed to removing some of the constraints that forced the government to rely on inflationary finance.

Under these circumstances, it is perhaps not surprising that two stabilization attempts in 1829 and 1833 failed. In 1829, Viamonte proposed a drastic plan whose ultimate goal was the restoration of the gold-peso parity. To this effect, the "Caja de Amortizacion de Billetes de Banco" was created - an institution whose only purpose would be to use tax revenues to retire the bank notes. The "Caja" was too successful as a collecting agency, however, and the government was, once again, tempted to renege on the promise that the "Caja's" funds would not be used for any other purpose. By November 1831, the short-term debt reached an unprecedented level of 3 million pesos and the interest bill was about 0.15 million per month (Burgin (1946), p. 162). Given the weakness in the bond market at the time, the government was hesitant to undertake a

\footnotetext{
${ }^{15}$ In 1844 service of the loan was partially resumed only to be suspended in 1845 .
} 
funding operation which would necessitate an issue of roughly 5 million pesos in long-term bonds. Therefore, it proposed to the Legislative Assembly - which readily approved it - that the government be able to use the more than 2 million pesos that the "Caja" had accumulated as of November 1831 to meet its obligations. The Assembly insisted that the government pay back the "Caja" in monthly installments of 50,000 pesos beginning in January 1833 . When this provision was about to come into effect, however, the legislature revoked the obligation of payment and suspended the operation of the "Caja" for a year. The "Caja," however, never saw the light of day again as the suspension proved to be permanent.

A similar plan was proposed by Garcia in 1833, during Viamonte's second administration. Garcia also proposed returning to the metallic standard of the early 1820s. It was estimated that the retirement of bank notes needed to effect the return to the gold parity would cost 2.5 million (silver) pesos. An additional 2 millions would be needed to extinguish the floating indebtedness of the province. Garcia suggested that a new loan could be obtained in London. Garcia's plan was received with little enthusiasm as it provided no immediate relief to the Treasury, at a time when there was a danger of suspending payments. The provincial legislature thus opted for approving a new issue of long-term bonds for 3 million pesos. The situation remained desperate, however, since the treasury owed a large sum of unpaid bills and borrowing against short-term bills implied an interest rate of 3.5 percent a month. Hence, the government had no choice but to issue additional long-term debt (Table 1).

\subsection{Rosas' rule, $\mathbf{1 8 3 5}-1851$}

By the early 1840 s, the treasury continued to be heavily dependent on trade taxes which, in normal times (i.e., when no blockade was in effect), constituted between 85 and 90 percent of total revenues (and in some years as much as 93 percent) (Table 1). In addition, the financial situation remained extremely fragile since various attempts at putting the house in order during relatively normal times (as in 1821, 1829, and 1833) kept failing. Hence, the economy was tremendously vulnerable to any conflict which involved higher expenditures and, most importantly, a successful blockade.

During the 17 years of Rosas' dictatorial rule (1835-1851), Buenos Aires was twice subjected to blockades by the French (1838-1840) and combined French and British fleets (1845-1848). During 1839 - the only full year of the French blockade - custom duties amounted to 2.3 million pesos compared to 9.1 million in 1837. In 1846, custom duties decreased to 6 million from 29.2 million in 1844 and 32.9 in 1843 (Table 1). Throughout Rosas' rule, military expenditures remained very high, never falling below 50 percent of total expenditures after 1839. Rosas was forced to maintain a large standing army since internal conflicts and external conflicts meant that war was almost a normal state of affairs.

Rosas was not willing to close the fiscal accounts by imposing a heavy tax burden on the powerful "estancieros." As in the past, the treasury resorted to a combination of debt and money issue. As bond prices increased in 1835 and 
1836, the authorities decided to issue long-term bonds once again. In January 1837, the government was authorized by law to issue 17 million pesos in bonds, the largest operation in the history of the "Fondos Publicos" (long-term bonds). The treasury estimated that it would have no difficulty in placing the bonds at 60 percent below par. In practice, however, it proved quite difficult and bonds were often trading below that. In 1840, the last bond issue under Rosas took place. Thereafter, long-term public indebtedness was reduced rapidly (Table 1). As a result, bond prices reached par in September 1846.

After 1840, Rosas apparently decided not to issue any additional long-term bonds, and relied exclusive on monetary financing. Such a decision may be explained by two main factors (Burgin (1946), p. 206). First, Rosas may have considered loans to be too costly since the government found it extremely difficult to sell them at less than a 40 percent discount. Each new bond issue rendered the market quite nervous and the Treasury had to be extremely cautious in this respect. Second, the "estancieros" - Rosas' natural constituency argued that since the "unitarios" would not buy bonds for political reasons, the burden of financing the deficit fell heavily on them. Furthermore, it was argued, bond financing was unnecessary since a much more effective method of financing, money issue, was available. Such political considerations would thus raise the costs of resorting to conventional methods - taxes and debt - to finance public spending. It was also argued that the scarcity of media of exchange was making credit more expensive and hampering the province's economic development.

The large amount of notes issued after 1840 can be clearly seen in Table 1 and Figure 3. Between 1836 and 1851 (the last full year of Rosas's administration), the cumulative net issue increased by a factor of 8.2. Over the same period the average exchange rate increased by a factor of 2.5 (Figure 1) and the price level doubled (Figure 2).

In a way, the exclusive reliance on money financing after 1840 completed a long process that began in 1813 with the first compulsory loan. During 18101821 , government paper became more and more "liquid." In 1822, paper money was issued and soon became inconvertible. Long-term bond financing became increasingly difficult afterwards. In 1840, Rosas apparently concluded that bond financing was no longer worth it, and money financing became the only other important fiscal tool (in addition to trade taxes).

\subsection{Transition (1852-1867)}

After Rosas' fall in 1852, an agreement on a new Constitution was reached. The province of Buenos Aires, however, soon rejected the agreement and declared itself independent from the rest of the country, known as the "Confederacion Argentina." From 1854 to 1862, the two governments co-existed resorting to symbolic wars and, more often, to blockades and discriminating tariffs. According to Alemann (1989), monetary financing in the province of Buenos Aires continued to be key in covering the military expenditure needed for these last 
years of civil war, as revenues covered only two-third of expenditures. ${ }^{16}$

The Confederacion could not compete economically with Buenos Aires (Buenos Aires was much better situated and imposed tariffs on goods destined to locations along the Parana river). In desperation, the Confederacion invaded Buenos Aires once again in 1859. After a series of battles, the country was unified and, in 1862 , Mitre was elected president of what was now called the "Republica Argentina." Not surprisingly, this period of intense civil wars (1859-1861) saw a large increase in the note issue (Figure 3 and Table 1). Between 1862 and 1865 , there was a large monetary contraction (almost half of the note issue was retired). Although convertibility was decreed in 1864, it could not be implemented until 1867 due to lack of reserves (the government was unable to secure an external loan) and the war with Paraguay (1865-1870).

For the next 50 years, Argentina attempted to adhere to the Gold Standard. However, convertibility was suspended in 1876 after several years of political unrest and rising levels of money-financed government deficits. Convertibility was restored in 1883 , but lasted only until January 1885 , at a time of financial crisis in Europe and following a period of expansionary monetary and fiscal policy. Again, inconvertibility thereafter until 1899 was associated with lax fiscal and monetary policy leading to debt default in 1890. In 1899 Convertibility was restored with the return to fiscal and monetary orthodoxy in 1896 and the establishment of a form of currency board. Argentina suspended convertibility in 1914, along with most other countries, at the outbreak of World War I. In the interwar period Argentina followed conservative monetary and fiscal policies, returned to gold during 1927-29, and in the 1930s followed mildly stimulative policies (see Cortes Conde (1979, 1989), Della Paolera (1995), and Della Paolera and Taylor $(1997,1998)$ ). A return to high inflation regimes, as in the nineteenth century, commenced with Peron after World War II (see Di Tella and Dornbusch (1989).

\section{The United States}

\subsection{Monetary conditions in the thirteen colonies}

Since all of the colonies were founded, chartered, and to some extent administered by the English government, their monetary systems were strongly influenced by English monetary regulations and practices. The principle medium of exchange in the colonies, as in England, was silver coins. No banks in the modern sense existed, so there were no deposits or bank notes. All thirteen colonies expressed their monetary unit of account in terms of the English denominations of pounds, shillings, and pence. Initially, the meaning of one pound was 3.87 ounces of silver which corresponded to a price of 5 shillings two pence per ounce of silver, as in England (McCallum, 1989, Chapter 15).

\footnotetext{
${ }^{16}$ Unfortunately, and to the best of our knowledge, data for this period are not readily available.
} 
One problem from the beginning was that the British Navigation Acts discouraged the export from England of English silver coins and the colonies were prohibited from setting up their own mints. Consequently, the bulk of coins used were Spanish silver coins, called "pieces of eight" or "dollars." A Spanish dollar was originally worth 7 shillings and 6 pence.

All of the colonies throughout the seventeenth and eighteenth centuries complained of a perennial "shortage" of silver. This may have reflected the tendency of developing countries to run chronic balance of payments deficits. It was likely aggravated by the Navigation Acts which were designed to maximize the English balance of trade surplus at the expense of her colonies. It may also have reflected deterioration in the quality of Spanish silver coins in an era before modern milling and minting techniques had been invented (Redish, 1984).

To counteract the shortage of specie, which was commonly believed to be a deterrent to continuous growth and prosperity, colonial governments resorted to a number of techniques. One was to legally declare that an ounce of silver in a specified coin was worth more shillings in the colony in question than elsewhere (for example, Massachusetts in 1672 declared the local value of silver at 6 shillings 10 pence per ounce) which was equivalent to a modern devaluation. The practice was prohibited by the English government in 1692. A second device was the use of commodity money - attaching official value to, for example, bales of tobacco in Virginia and allowing titles of ownership to circulate as money.

The third device, and the one most commonly used, was the issue of paper money in one of two forms: land bank bills which were IOUs based on the security of mortgages (used principally in Rhode Island); and bills of credit notes issued by the colonial government promising to repay the holder in specie at some future date based on the collection of taxes. These bills, also referred to as "tax anticipation warrants," were freely transferable without endorsement from holder to holder, were issued in convenient denomination, and were printed in a form somewhat similar to today's money. These bills of credit came to be quickly accepted as a medium of exchange and serve as a major form of colonial currency. The greatest issue of these bills was in wartime to finance military expenditures, although some colonies also issued them to finance ordinary government expenditures.

In the first half of the eighteenth century, the New England colonies (most notably Rhode Island) as well as South Carolina issued sufficient amounts to displace all specie from the money supply and hence force the colony off the fixed exchange rate specie standard. This led to rapid inflation and depreciating exchange rates (Michener (1987), McCallum (1992)). Other colonies (most notably the Middle Atlantic states) did not issue enough paper money to displace specie and force them off the fixed exchange rate standard and hence their experiences were associated with low inflation and stable exchange rates. ${ }^{17}$

\footnotetext{
${ }^{17}$ According to Smith $(1985 \mathrm{a}, 1985 \mathrm{~b})$, the presence or absence of a correlation between issuance of bills of credit and inflation and depreciation depended on whether the bills were credibly backed by future tax revenues. In the middle Atlantic states they were, while in New England and South Carolina they were not. McCallum (1992) and Michener (1987) dispute this interpretation on grounds of both theory and evidence.
} 
In reaction to the New England experience of high inflation from 1720-50, the British Board of Trade imposed the Currency Act of 1751 prohibiting those colonies from issuing bills of credit not fully backed by specie. As a consequence, the New England colonies financed the Seven Years War by the issue of shortterm treasury notes, which were quickly retired after the war with tax revenues. The other colonies issued bills of credit backed by future taxation which after the war were also retired. The prohibition on paper money issue was extended to the other colonies in 1764 - although not universally followed. The 1764 prohibition on the issue of paper money by colonies which had not abused the privilege in turn became one of the sources of resentment leading to rebellion a decade later (Perkins, 1994, pp. 42-55).

\subsection{The War of Independence}

Like Argentina, United States' history began with a revolutionary war, which by modern standards was quite large (military expenditures of $15-20$ percent of GNP versus World War II at 40 percent). The states and the Congress in 1775 intended to finance the war in the same manner as the Seven Years war but, as events unfolded, it was in large part ( 85 percent) financed by the issue of fiat money by the Congress and the states. The Congress had virtually no taxing power, while that of the states was too limited to pay for more than a small fraction of total expenditure. Foreign bond finance was hobbled by uncertainty on the wars outcome and domestic bond issues were limited by a thin market.

The federal government's initial strategy was to issue paper money to be redeemed by state tax issues. When these were not forthcoming, further issues of continentals ensued. Paper money issues at the rate of 50 percent per year (Figure 5) in the first five years of the war generated a very rapid inflation rate of over 65 percent per year (Figure 6) and rapid depreciation of the exchange rate (Calomiris, 1988). The inflation ended after a currency reform in 1780 under which the federal government stopped issuing bills of credit, and the states agreed to accept outstanding bills in payment of taxes at 40 dollars to 1 in specie (a value much lower than the exchange rate of 1780) until 1783, after which date the continental would become worthless. ${ }^{18}$ Once it became apparent that the United States would win the war, loans from Holland and France and from domestic sources greatly reduced the need for note issue.

After the war, many of the states succeeded in paying off a significant portion of the outstanding debt and even some of the federal government's debt, by drastically raising taxes. They followed a model successfully developed during the Seven Years War of 1757 to 1763 of using paper money and short-term bond finance during the war and rapid redemption through high taxation immediately thereafter (Perkins, 1994, pp. 88-95). Some states reissued paper money but unlike during the War of Independence, they were credibly backed by future taxes. In at least two states (Massachusetts and South Carolina) the tax burden

\footnotetext{
${ }^{18}$ The Congress also issued a new form of paper currency "the new tenor" at 20 to 1 . These bills quickly depreciated by 50 percent and were then made convertible into specie in 1783 .
} 
became so heavy that it led to civil unrest followed by a considerable reduction in tax rates. By contrast, the federal government, unable to raise taxes on its own both before and under the 1783 Articles of Confederation, defaulted in 1782 on both its domestic debt and debts to France. ${ }^{19}$ An attempt to improve the federal government's finances by creating a bank of issue to provide temporary bridge loans - the Bank of North America founded in 1781 - was of limited value. ${ }^{20}$

A successful resolution of the federal government's fiscal problem finally came after a new constitution was adopted in 1789 which gave the federal government greatly expanded powers in monetary and fiscal affairs including the ability to raise tax revenues and the sole right to issue currency. ${ }^{21}$ Alexander Hamilton, the Secretary of the Treasury from 1789 to 1795, put together one of the most successful financial programs in history. The package included four elements: funding the national debt, creation of a Sinking Fund, securing sufficient tax revenue, and creation of the First Bank of the United States.

Funding the National Debt Alexander Hamilton believed that by converting outstanding federal and state debt obligations into long-term bonds and by creating mechanisms to both service and amortize this debt, he could create an effective capital market to facilitate future government borrowing in wartime. Consequently, he worked out a plan designed to fund the debt (both federal and state) in his June 1790 Report on the Public Credit to Congress. This involved converting outstanding paper securities into specie denominated securities at the official par of exchange. Outstanding federal domestic debt was roughly $\$ 40$ million ( $\$ 27$ million in original principal plus $\$ 13$ million in accrued interest), foreign debt was approximately $\$ 12$ million and state debts were $\$ 15$ to $\$ 25$ million (Perkins, 1994, p. 214). The debts of various maturities plus arrears were converted into a debt package that greatly reduced the effective interest rate to well below the 6 percent rate stipulated on most public securities outstanding in $1789 .{ }^{22}$ The bonds issued were similar to British consols with no specific retirement date. ${ }^{23}$ Shortly after successful conversion and funding of the debt, U.S. government securities became quickly accepted both at home and abroad and yields fell to rates comparable to bonds of the leading European powers (Perkins, 1994, p. 218).

\footnotetext{
${ }^{19}$ The Dutch loaus were continuously serviced. The difference in treatment between the two foreign powers is that the French loans were viewed as political, the Dutch as strictly commercial. Secretary of the Treasury Morrison realized the benefits in terms of future access of continuously servicing the Dutch loans (Perkins (1994, pp. 108-109), Garber (1991)).

${ }^{20}$ The Bank of North America did not obtain a national charter but it did serve as a depository for government funds. It was a conservatively managed bank which continuously followed specie convertibility and engaged primarily in commercial lending.

${ }^{21}$ The Coinage Act of 1792 defined United States currency as both gold and silver. The original bimetallic standard was set at a mint ratio for gold to silver of 15 to 1 .

${ }^{22}$ Some discrimination occurred in paying off different classes of boudholders. Dutch investors received full value. French and domestic holders did not receive interest on arrears and domestic holders were compensated in specie based on the face value of the bonds rather than the market value (Garber, 1991).

${ }^{23}$ Also, the majority of bonds were non-callable in any given year (Perkins (1994), p. 218).
} 
A sinking fund The fund principle was set in place by the Funding Act of August 4, 1790, which pledged the proceeds of the sales of public lands in the western territories solely to the redemption of the debt. A regular sinking fund was created by the act of May 8, 1792 "to which were invariably pledged the interest of previously-retired debt and the surplus of all sums appropriated for the payment of interest on the debt [and] a commission was directed to make purchases for this fund and to render appropriate accounts" (Dewey (1920, p. 113). An act of March 3, 1795 made explicit the revenues to be devoted to the fund, including part of import duties, excise taxes, and the sale of public lands.

Following the British example of 1717, Hamilton proposed a sinking fund as a way of ensuring the credibility of his funding program. The idea was to set aside revenues derived from specific taxes, from the post office, and from government budget surpluses to be used to purchase public securities on the open market. The interest earned by the sinking fund would be used to acquire more public securities and eventually pay off the debt. A key feature was that the monies accumulated by the fund could not be diverted by the Congress at a later date for other expenditures. ${ }^{24}$

Tax revenues Of great importance to Hamilton's package was the government's ability to collect sufficient tax revenues to continuously service the debt. In his view, debt service was paramount in creating the conditions for a well functioning long-term capital market-an institution he viewed as essential for both future economic development and successful public finance. He was opposed to the Jeffersonian approach to public finance which advised raising taxes sufficiently to retire debt within a generation (Perkins, 1994, Chap. 9). Consequently, he proposed a national tariff sufficient to generate revenues equal to 10 percent of import values (about $\$ 5$ million annually or 2 percent of 1792 GNP (Perkins, 1994, p. 232)). Tariff revenues were to be supplemented by excise taxes on alcohol and other levies. ${ }^{25}$ Later on in the nineteenth century, revenues from the sale of public lands became an increasingly important source of federal government revenue.

The First Bank of the United States A key component of Hamilton's financial package was the creation of a national bank of issue. This monopoly bank, modelled after the Bank of England, would have both public and private ownership and would provide loans to both sectors. It would be sufficiently well capitalized to be able to provide the government with medium-term (one to two

\footnotetext{
${ }^{24}$ In the years preceding the War of 1812 , the fund was successful in retiring much of outstanding government debt, including a loan from the First Bank of the United States. After the war of 1812, in 1816 and 1817 the Secretary of the Treasury pledged annual appropriations from the budget surplus to the sinking fund. In 1817, the accounts of the fund were greatly simplified so that public debt when redeemed was to be destroyed - in effect much of the original Hamiltonian apparatus was removed (Dewey, 1920, p. 171). The sinking fund was revived for a few years after the Civil War but was not used consistently by successive treasury secretaries (Dewey, 1920, p. 351).

${ }^{25}$ The excise tax on alcohol was very unpopular, leading to the Whiskey Rebellion of 1794 and was repealed by President Jefferson in 1805.
} 
years) bridge loans to finance shortfalls in government tax receipts. It was also hoped that its loans to the private sector would spur economic development but it was deemed imperative that it also hold sufficient specie reserves to always maintain convertibility of the notes.

The First Bank of the United States was chartered in 1791 with a capital of $\$ 10$ million (it was the largest business enterprise in the country). One fifth of its shares were purchased by the government; the rest by the private sector. In the 1790s the Bank was used by the government to cover shortfalls in tariff revenue. Within a decade however, the government repaid its debt to the Bank and by 1805 sold off all of its shares. In its second decade of operation, the First Bank acted solely as a commercial bank, but its large size, nationwide branches, and deep reserves allowed it to act as a primitive central bank for the nascent state-chartered commercial banking system. In the face of mounting criticism of its privileged position and an ongoing challenge of its constitutionality by the now dominant Jeffersonians, renewal of its charter was denied in 1811 and its doors closed in the following year.

In sum, the movement towards monetary and fiscal orthodoxy after the Revolution was a reaction to the losses of wealth and disruptions associated with the continental-induced inflation. But it also was a reaction to earlier inflationary episodes under the colonial regime.

\subsection{The War of 1812}

The War of 1812 was only one fifth as costly as the War of Independence and 85 percent was financed by borrowed money (Perkins, 1994, p. 326). In the decade before the war, the Jefferson and Madison administrations dismantled some of the planks in the Hamilton platform by retiring half of the national debt (Figure 8 ) and not renewing the charter of the First Bank. As wartime expenditures mounted, the government turned to bond finance, but it was unable to cover all its expenditures at acceptable rates, so it turned to a form of paper money issue - the Treasury note. These notes of one to two year maturities, issued in varying denominations, bore interest. The smaller denomination notes circulated as hand to hand currency thereby pumping up the money supply. The larger notes served as bank reserves for the commercial banks also fueling monetary expansion (Timberlake, 1993, Chapter 2). Monetary expansion led to rapid inflation of 55 percent in 1813-1814 (Figures 5 and 6). The commercial banks in the middle Atlantic and Southern states were forced to suspend specie convertibility in 1814, followed by the U.S. government after the British capture of Washington. The exchange rate also depreciated (Figure 7 ). The government's difficulties in securing wartime finance led to renewed calls for a recharter of the Bank of the United States. The Second Bank was established on terms similar to the First Bank but with a substantially larger capital of $\$ 50$ million. In its first year of operation, it helped the commercial banks accumulate sufficient specie reserves to restore convertibility in 1816 . Within three years of the war, the Treasury had raised sufficient revenues to completely retire its outstanding note issues.

For the period 1816 to 1861 the United States adhered to specie convertibility 
with the exception of suspensions of payments in the face of financial crises in 1837-38 and 1857. During this period the price level and exchange rate varied considerably (Figures 6 and 7 ) reflecting specie movements associated with external influences on the balance of payments. ${ }^{26}$

This 45-year period was punctuated by a war with Mexico in 1846-48, whose associated military expenditure of $\$ 64$ billion was entirely financed by borrowing (Dewey, 1920, p. 255). Continuous wars with the Indians were funded through normal government revenues. Throughout this period, the government ran persistent budget surpluses (Figure 9), which were used to retire outstanding debt (Figure 8). From a peak of $\$ 127$ million in 1815 , the debt fell close to zero in 1834, it increased to $\$ 68$ millions after the Mexican War and then declined to $\$ 45$ million on the eve of the Civil War (Historical Statistics of the United States, 1976).

\subsection{The American Civil War}

The American Civil War incurred costs for the federal government quite similar to the War of Independence -15 to 20 percent of GNP. Unlike the War of Independence, 62 percent of the war was financed by bonds, 13 percent by the issue of paper money, 21 percent by taxes, and the rest from miscellaneous sources (Friedman, 1952). ${ }^{27}$ The federal government originally intended to finance its operations solely through borrowing and taxation but by the end of 1861 found it difficult to sell its bonds at favorable rates. Beginning in early 1862 it began issuing paper money-the greenbacks (non-interest bearing notes denominated in dollars and declared to be legal standard). Under the Legal Tender Acts, these notes were issued on the presumption that they would be convertible, but the dates and provisions for convertibility were not specified. The government issued $\$ 450$ million in greenbacks during the war.

In addition a further $\$ 300$ million were issued by the national banks-an institution created in 1863 (Figure 5). Prices rose by 25 percent per year. In January 1862 the commercial banks suspended specie convertibility and the dollar began a rapid depreciation against sterling, peaking in 1865 (Figure 7).

Shortly after the war, the government made clear its intentions to restore specie payments at the prewar parity in the Contraction Act of April 12, 1866. Over the next 12 years the price level followed a declining path, largely reflecting rapid real growth in the face of a constant money supply, so that by 1878 purchasing power parity with Britain had been restored at the prewar level and successful resumption was achieved (Friedman and Schwartz, 1963).

\footnotetext{
${ }^{26}$ Many historians have argued that a period of rapid inflation in the early 1830 s was associated with an excess note issue by the state banks after the demise of the Second Bank of the United States. A revisionist view, however, attributes it to external events (Macesich 1960, Temin 1969).

${ }^{27}$ In the Confederacy, 60 percent of government expenditures were financed by paper money, 30 percent by taxes, and the rest from miscellaneous sources (Lerner, 1959). This generated a massive inflation - over the period the price level increased 92 times. The question of why the Confederacy did not undertake more external borrowing is tackled in Grossman and Han (1996).
} 
During that period, however, a fierce debate raged between the hard- money forces-advocates of rapid resumption and the soft-money forces, some of whom were opposed to restoring the specie standard, others who wanted to restore it at a devalued parity and yet others who just wanted to prevent any undue deflation and allow the economy to grow up to the money supply (Unger (1964), Sharkey (1959)). Alternating victories by the conflicting forces were manifest in legislation, alternatively contracting and expanding the issue of greenbacks (the Public Credit Act of 1869 contracting it, the reissue of $\$ 26$ million of retired greenbacks in 1873 expanding it); and in Supreme Court decisions, initially declaring the legal Tender Acts unconstitutional (Hepburn vs Griswold, February 1870), and then reversing the decision (Knox vs Lee May 1871). Finally the decision to resume payments on January, 1879 was made in the Resumption Act of 1875 . Despite the announcement of resumption, however, and of steps taken by the Treasury to accumulate a gold reserve and to retire greenbacks, the bitter election of 1876 was fought between Cooper, the Greenback candidate, who was opposed to resumption; Tilden, a soft-money Democrat; and Hayes a hard money Republican. Hayes won by one electoral vote. Yet, had Tilden won, according to one authority, resumption would not have been prevented; only the date may have been changed (Unger (1964), pp. 310-11).

The United States resumed gold payments on January 1, 1879 and adhered to gold convertibility until 1933 with the exception of a wartime embargo on gold exports during 1918-19. Over the period 1879-1917 (with the principal exception of the agitation over silver in the 1890s and the Spanish American War of 1898 , which was financed largely by borrowing and special excise taxes (Dewey, 1920, p. 456)), the United States followed conservative monetary and fiscal policies-generally running a series of budget surpluses.

\section{A dynamic public finance model}

The pattern exhibited for the United States of wartime expenditures financed in the main by debt and, to a lesser extent, the inflation tax, followed by peacetime debt retirement and deflation (with the exception of the War of Independence) is in marked contrast to that of Argentina. In the latter case, each successive war was financed more and more by the inflation tax, while peacetime episodes exhibited at best a halt to inflation and limited debt retirement. This section and the next offer an explanation for these contrasting patterns in terms of a dynamic public finance model.

Consider a small open economy perfectly integrated with the rest of the world in both goods and assets markets. The exchange rate is predetermined (i.e., the government sets the rate of devaluation). ${ }^{28}$ This section presents the consumer's and the government's problem; the next section derives the main results related to war finance.

\footnotetext{
${ }^{28}$ The same analysis would go through under flexible exchange rates.
} 


\subsection{Household's problem}

There is only one (nonstorable) good, which is produced with labor as the only input. Labor is taken to be the numeraire. Production takes place under a constant-returns-to-scale technology given by $y_{t}=n_{t}$, where $y$ denotes production of the good, $n$ stands for labor, and units have been so defined that producing one unit of the good requires one unit of labor. Carrying out transactions is costly in that it requires the use of "shopping time," denoted by $s$. The representative household is endowed with one unit of time. Its time constraint is thus given by

$$
s_{t}+n_{t}+h_{t}=1
$$

where $h$ denotes leisure.

Households may hold two assets: domestic (non-interest bearing) money and an internationally-traded bond which bears a (constant) real rate of return, $r$. Households hold real money balances in order to reduce shopping time. Specifically, shopping time is given by

$$
s_{t}=v\left[\frac{m_{t}}{c_{t}\left(1+\theta_{t}\right)}\right] c_{t}\left(1+\theta_{t}\right)
$$

where $m$ denotes real money balances, $c$ stands for consumption, $\theta$ is the consumption $\operatorname{tax}$, and $v($.$) , the transactions technology, satisfies the following prop-$ erties:

$v() \geq 0,. v^{\prime}() \leq 0,. v^{\prime \prime}()<0,. v^{\prime \prime \prime}()=0,. v^{\prime}\left(X^{s}\right)=0, v\left(X^{s}\right)=0,0 \leq X \leq X^{s}$,

where $X^{s}=\frac{m}{c(1+\theta)}$ will be referred to as "relative money balances." Additional units of relative money balances bring about positive but diminishing reductions in shopping time. There exists a level of relative money balances, $X^{s}$, such that the gains from holding additional liquidity are exhausted (i.e., $v^{\prime}\left(X^{s}\right)=0$ ). Transactions costs at that point are assumed to be zero (i.e., $v\left(X^{s}\right)=0$ ). ${ }^{29}$

The household's budget constraint is given by

$$
f_{t}=(1+r) f_{t-1}+1-h_{t}-c_{t}\left(1+\theta_{t}\right)-s_{t}+\frac{m_{t-1}}{1+\pi_{t}}-m_{t},
$$

where $f$ denotes real bond holdings, and $\pi_{t}$ is the rate of inflation (and devaluation, given that the law of one price holds), defined as the percentage change in the price level between periods $t-1$ and $t$.

\footnotetext{
${ }^{29}$ As will become clear below, the assumptions that $v($.$) exhibits constant returns to scale$ and that $v\left(X^{s}\right)=0$ are critical in ensuring that the optimal inflation tax is zero when there are no collection costs.
} 
The household's maximization problem thus consists in choosing $\left\{c_{t}, h_{t}, m_{t}\right\}$ for $t=0,1, \ldots$, to maximize

$$
\sum_{t=0}^{\infty} \beta^{t}\left[\log \left(c_{t}\right)+\log \left(h_{t}\right)\right],
$$

subject to equation (4), with $s_{t}$ given by (2). Assuming an interior solution, the first-order conditions for this problem are given by

$$
\begin{aligned}
\frac{1}{c_{t}} & =\lambda\left(1+\theta_{t}\right)\left[1+v\left(X_{t}\right)-v^{\prime}\left(X_{t}\right) X_{t}\right], \\
\frac{1}{h_{t}} & =\lambda \\
-v^{\prime}\left(X_{t}\right) & =I_{t}
\end{aligned}
$$

where $\lambda$ is the (constant) multiplier associated with budget constraint (4) and $I_{t}\left(\equiv \frac{i_{t}}{1+i_{t}}\right)$ is the inflation tax..$^{30,31}$ Equation (6) is the familiar condition whereby, at an optimum, consumers equate the marginal utility of consumption to the shadow value of wealth $(\lambda)$ times the effective price of consumption. The effective price of consumption is given by the real market price, $1+\theta$, plus the increase in shopping time associated with an additional unit of consumption, $v\left(X_{t}\right)(1+\theta)-v^{\prime}\left(X_{t}\right) X_{t}(1+\theta)$. Condition (7) implies that, along a perfect foresight equilibrium path, leisure will be constant. Equation (8) states that, at an optimum, consumers equate the marginal reduction in transaction costs derived from holding an additional unit of real money balances to its marginal cost, $I .^{32}$

For further reference, note that the effective price of consumption may also be viewed as the effective tax rate faced by the consumer. In effect, solving for $X$ as a function of $I$ from (8) and substituting into (6), we obtain:

$$
\frac{1}{c_{t}}=\lambda q\left(\theta_{t}, I_{t}\right)
$$

where

$$
q\left(\theta_{t}, I_{t}\right) \equiv\left(1+\theta_{t}\right)\left\{1+v\left[\tilde{X}\left(I_{t}\right)\right]-v^{\prime}\left[\tilde{X}\left(I_{t}\right)\right] \tilde{X}\left(I_{t}\right)\right\}
$$

\footnotetext{
${ }^{30}$ As usual, and to eliminate inessential dynamics, we assume that $\beta(1+r)=1$. This implies that $\lambda_{t}=\lambda$ for for all $t$.

${ }^{31}$ The nominal interest rate, $i$, is defined as $i_{t} \equiv(1+r)\left(1+\pi_{t+1}\right)-1$.

${ }^{32}$ The intuition behind $I$ (rather than $i$ ) being the relevant inflation tax is as follows. By holding $M_{t}$ during period $t$, the household foregoes $i_{t} M_{t}$, which would have had a real value in $t+1$ of $\frac{i_{t} M_{t}}{P_{t+1}}=\frac{i_{t} m_{t}}{1+\pi_{t+1}}$. Discounted back to period $t$, this has a value of $\frac{i_{t} m_{t}}{(1+r)\left(1+\pi_{t+1}\right)}=$ $\frac{i_{t} m_{t}}{\left(1+i_{t}\right)}$.
} 
is the effective tax rate. The household will therefore care about the effective tax rate and not about its composition.

For our purposes, a key characteristic of the consumer's program is that the optimal path of leisure is not affected by government policy; that is, it does not depend on the path of either the consumption tax or the inflation tax. To show this, use (10) to rewrite the consumer's flow constraint (4) as

$$
a_{t}=(1+r) a_{t-1}+1-h_{t}-q\left(\theta_{t}, I_{t}\right) c_{t}
$$

where

$$
a_{t} \equiv f_{t}+\frac{m_{t}}{1+i_{t}}
$$

denotes real financial assets. Using (6) and (7), (11) can be rewritten as

$$
a_{t}=(1+r) a_{-1}+1-2 h_{t}
$$

Integrating forward, imposing the corresponding transversality condition, and recalling from $(7)$ that $h_{t}$ is constant along a perfect foresight path, we obtain:

$$
h_{t}=\frac{1}{2}\left(r a_{t-1}+1\right) .
$$

Equation (13) indicates that leisure will always be equal to one-half of permanent income. In what follows, and with no loss of generality, we assume that $a_{-1}=0$, so that $h_{t}=\frac{1}{2}$. The fact that leisure does not depend on either the consumption tax or the inflation tax will greatly simplify the optimal tax problem faced by the government. ${ }^{33}$

\subsection{Government's problem}

The government faces an exogenously-given path of government spending, $g$, which it can finance by means of a consumption $\operatorname{tax}, \theta$, the inflation tax, $I$, or by borrowing in world financial markets. ${ }^{34}$ Following the primal approach to optimal taxation (see, for instance, Lucas and Stokey (1983)), the government will choose an optimal allocation subject to the constraint that such an allocation be implementable as a competitive equilibrium (a Ramsey allocation). In other words, the household's optimality conditions imply some "implementability" conditions, which will restrict the set of allocations that the government can choose from. Given an optimal allocation, the household's problem will determine the taxes that are needed to implement such an allocation.

\footnotetext{
${ }^{33}$ Both the Cobb-Douglas utility function - which implies constant expenditures shares and the homogeneity of degree one of the transaction costs technology are critical assumptions in this respect.

${ }^{34}$ Note that since the consumption tax applies to a traded good, it is essentially the same as a trade tax.
} 
Implementability conditions In this optimal taxation problem, there are three implementability conditions. The first is that, as shown above, $h_{t}=1 / 2$. Given that, in a competitive equilibrium, leisure will always be equal to one-half, the government cannot choose any other leisure allocation and will therefore take leisure as given. From (7), this implies that $\lambda=2$. The other two implementability conditions, which follow from first-order conditions (6) and (8), are given by

$$
\begin{aligned}
\theta_{t} & \equiv y^{\theta}\left(c_{t}, X_{t}\right)=\frac{1}{\lambda c_{t}\left[1+v\left(X_{t}\right)-v^{\prime}\left(X_{t}\right) X_{t}\right]}-1 \\
I_{t} & \equiv y^{I}\left(X_{t}\right)=-v^{\prime}\left(X_{t}\right)
\end{aligned}
$$

Total differentiation of (14) and (15) yields:

$$
\begin{aligned}
y_{c}^{\theta}\left(c_{t}, X_{t}\right) & =-\frac{\left(1+\theta_{t}\right)}{c_{t}} \\
y_{X}^{\theta}\left(c_{t}, X_{t}\right) & =\frac{v^{\prime \prime}\left(X_{t}\right) X_{t}\left(1+\theta_{t}\right)}{1+v\left(X_{t}\right)-v^{\prime}\left(X_{t}\right) X_{t}}, \\
y^{I \prime}\left(X_{t}\right) & =-v^{\prime \prime}\left(X_{t}\right) .
\end{aligned}
$$

By taking into account restrictions (14) and (15), which imply (16)-(18), the government will ensure that the allocation it chooses is implementable as a competitive equilibrium.

Government budget constraint The collection of the consumption tax is assumed to carry collection costs. The government's budget constraint in each period is given by

$$
z_{t}=(1+r) z_{t-1}+\theta_{t} c_{t}-T\left(\theta_{t} c_{t}\right)+m_{t}-\frac{m_{t-1}}{1+\pi_{t}}-g_{t}
$$

where $z_{t}$ denotes the government's stock of internationally-traded bonds at the end of period $t$, and $T\left(\theta_{t} c_{t}\right)$ represents the collection costs associated with the consumption tax. ${ }^{35}$ For simplicity, it will be assumed that $T(\theta c)=k(\theta c)^{2}$, where $k$ is a non-negative (and possibly time-varying) parameter that will play a key role in determining the optimal level of taxes. Taking into account the explicit collection costs function and the definition of $X$, equation (19) can be rewritten as

$$
b_{t}=(1+r) b_{t-1}+\left(1-k_{t} \theta_{t} c_{t}\right) \theta_{t} c_{t}+I_{t} X_{t} c_{t}\left(1+\theta_{t}\right)-g_{t},
$$

\footnotetext{
${ }^{35}$ Collection lags (the so-called "Tanzi effect") could be incorporated along the lines of Dixit (1989). The main results would not change.
} 
where $b_{t} \equiv z_{t}-\frac{m_{t}}{1+i_{t}}$ denotes net government's assets at the end of period $t$. Equation (13) thus says that government's net assets increase if interest income and tax revenues exceed government spending. ${ }^{36}$

Finally, the government's budget constraint can be expressed solely as a function of quantities, $c$ and $X$, by substituting (14) and (15) into (19) to obtain:

$$
b_{t}=(1+r) b_{t-1}+\Gamma\left(c_{t}, X_{t}\right)-g_{t}
$$

where

$$
\Gamma\left(c_{t}, X_{t}\right) \equiv\left[1-k_{t} y^{\theta}\left(c_{t}, X_{t}\right) c_{t}\right] y^{\theta}\left(c_{t}, X_{t}\right) c_{t}+y^{I}\left(c_{t}, X_{t}\right) X_{t} c_{t}\left[1+y^{\theta}\left(c_{t}, X_{t}\right)\right]
$$

denotes total tax revenues.

Ramsey allocations The government's maximization problem thus consists in choosing a path for $c$ and $X$ to maximize (5) subject to (21) (and taking as given $h_{t}$ ). Taking into account (16)-(18) and assuming interior solutions, the first-order conditions for this problem imply that:

$$
\begin{aligned}
\frac{1}{c_{t}} & =-\gamma \Gamma_{c}\left(c_{t}, X_{t}\right), \\
\gamma \Gamma_{X}\left(c_{t}, X_{t}\right) & =0
\end{aligned}
$$

where

$$
\begin{aligned}
\Gamma_{c}\left(c_{t}, X_{t}\right)= & -\left[1-2 k_{t} y^{\theta}\left(c_{t}, X_{t}\right) c_{t}\right] \\
\Gamma_{X}\left(c_{t}, X_{t}\right)= & -c_{t}\left[1+y^{\theta}\left(c_{t}, X_{t}\right)\right] \\
& \times\left[v^{\prime}\left(X_{t}\right)+\frac{v^{\prime \prime}\left(X_{t}\right) X_{t}\left[v\left(X_{t}\right)+2 k_{t} y^{\theta}\left(c_{t}, X_{t}\right) c_{t}\right]}{1+v\left(X_{t}\right)-v^{\prime}\left(X_{t}\right) X_{t}}\right],
\end{aligned}
$$

and $\gamma$ is the (constant) multiplier associated with constraint (21). Equations (21), (23), and (24) determine the optimal values of $c_{t}, X_{t}$, and $\gamma$. For given

\footnotetext{
${ }^{36}$ It is important to note that we have implicitly assumed that the government acts "honestly" in the sense of Auernheimer (1974), which implies that problems of time- inconsistency are assumed away, as pointed out by Calvo (1978). In the present context, this means that when the public wishes to increase (decrease) its real money holdings, the government provides (retires) nominal money balances to (from) the public in exchange for bonds. The government would act "dishonestly" if, say, it devalued to accommodate a reduction in real money demand, thus imposing a capital levy. Put differently, the government does not benefit (in terms of revenues) from changes in the stock of real money balances (other than through changes in revenues from the inflation tax, $I m$ ). (See Lucas and Stokey (1983) for an analysis of time inconsistency in an optimal taxation context.)
} 
values of $c_{t}$ and $X_{t},(14)$ and (15) determine the optimal values of $\theta$ and $I$ (recall that $\lambda$ is determined from the household's problem by the constant value of $h_{t}$ ).

At an optimum, $\Gamma_{c}\left(c_{t}, X_{t}\right)<0 .{ }^{37}$ In other words, at an optimum, an additional unit of consumption lowers revenues. Therefore, equation (23) says that, at an optimum, the government equates the marginal utility of consumption to the shadow value of government's wealth, $\gamma$, times the marginal loss in revenues from an additional unit of consumption. Also, at an optimum, $\Gamma_{X}\left(c_{t}, X_{t}\right)=0 .{ }^{38}$ Since an additional unit of $X$ has no direct effect on household's utility, first-order condition (24) says that, at an optimum, it is optimal to set the marginal increase in revenues from an additional unit of $X$ to zero.

\subsection{Current account}

Combining the consumer's flow budget constraint (equation (4)) and the government's (20), taking into account equation (2) and that $y_{t}=n_{t}$, yields the economy's flow resource constraint (i.e., the current account balance):

$$
f_{t}+z_{t}=(1+r)\left(f_{t-1}+z_{t-1}\right)+\frac{1}{2}-c_{t}-g_{t}-s_{t}-k_{t}\left(\theta_{t} c_{t}\right)^{2} .
$$

Equation (27) says that the economy accumulates net external assets as long as income (interest on net external assets and gross output, which equals onehalf) exceeds absorption (private and public consumption and the resources lost in shopping and tax collection).

\section{War and Inflation: Theoretical Predictions}

This section derives the optimal tax policy for different scenarios.

\subsection{Full tax smoothing}

The first two propositions describe situations in which it is optimal to completely smooth out taxes over time.

Proposition 1 (No collection costs). Suppose that $k_{t}=0$ for all $t$. Then the optimal tax policy consists of setting the inflation tax to zero and setting a constant consumption tax which finances permanent government spending in every period.

Proof. See Appendix.

Proposition 1 is Barro's (1979) celebrated tax-smoothing result derived in a monetary, public finance model. In the absence of collection costs, it is also the

\footnotetext{
${ }^{37}$ It can be checked that for the second-order conditions to hold, it must be the case that $\Gamma_{\mathfrak{c}} \Gamma_{X X}>0$. Since, as follows from $(26), \Gamma_{X X}<0$, then $\Gamma_{c}<0$. By (23), it follows that, at an optimum, $\gamma>0$.

${ }^{38}$ Since, at an optimum, $\gamma>0,(24)$ implies that $\Gamma_{X}\left(c_{t}, X_{t}\right)=0$.
} 
case that it is optimal not to resort to the inflation tax. ${ }^{39}$ Intuitively, recall from (10), that all that matters to the household is the effective tax on consumption. Households are thus indifferent about different combinations of taxes which yield the same effective tax. Socially, however, using the consumption tax entails no resource costs, while the inflation tax does. It is thus optimal to use only the consumption tax.

In this case, therefore, any excess of actual government spending over its permanent value (due to wars, for example) will be fully financed by running down the government's stock of internationally-traded bonds (i.e., by increasing the public debt). ${ }^{40}$ The current account thus deteriorates one-to-one with the temporary component of government spending. ${ }^{41}$ Under this optimal tax policy, the intertemporal distortion is completely eliminated and only the intratemporal distortion remains; that is, $q(\theta, I)=1+\theta>1 .^{42}$

Proposition 2 (Positive collection costs). Suppose that $k_{t}=k>0$. Then, both $I$ and $\theta$ are positive and constant over time.

\section{Proof. See Appendix.}

Proposition 2 shows that, with positive but constant collection costs, fulltax smoothing continues to be the optimal policy. The government, however, finds it now optimal to set positive values of both the consumption and the inflation tax. Intuitively, and unlike the previous case, both the consumption tax and the inflation tax carry resource costs. Hence, at an optimum, the government will be using both taxes. The dashed paths in Figure 11 illustrate these results: when the path of $k_{t}$ is constant over time, both the consumption and the inflation tax are positive but flat over time.

As shown in Végh (1989), a higher level of permanent government spending or a higher $k$ imply a higher (but still constant over time) inflation tax. As in the case described in Proposition 1, full tax-smoothing implies that there is no intertemporal distortion. The intratemporal distortion, however, is higher than in Proposition 1 (and, thus, welfare is lower) because collecting the consumption tax is now socially costly and the positive inflation tax generates positive transactions costs. Hence, collecting the same amount of revenues will require a higher effective tax rate.

\footnotetext{
${ }^{39}$ This is Kimbrough's (1986) result. The critical assumptions behind this result are the homogeneity of degree one of the transactions costs functions and the assumption that $v\left(X^{s}\right)=$ 0 . On the generality of this result, see Mulligan and Sala-i-Martin (1997). For our purposes, we want to have a benchmark case in which the optimal inflation tax is zero to ensure that deviations from this rule are due to economically relevant factors.

${ }^{40}$ Permanent government spending, $\bar{g}$, is defined as that constant value of government spending whose present discounted value is the same as that of actual government spending. Formally, $\bar{g}=\frac{r}{(1+r)} \sum_{t=0}^{\infty}\left(\frac{1}{1+r}\right)^{t} g_{t}$.

${ }^{41}$ Sec Ahmed (1986) for an empirical testing of Barro's full tax-smoothing hypothesis for the United Kingdom.

${ }^{42} \mathrm{Naturally}$, in a first best social optimum (i.c., a planner who can resort to lump-sum taxes), $q(\theta, I) \equiv 1$.
} 


\subsection{Time-varying collection costs}

The cases described in Propositions 1 and 2 do not provide a rationale for the inflation tax to increase in times of war. A key assumption behind these results is that $k_{t}$ does not change over time. This, however, may not always be a realistic assumption because wars are often likely to be associated with an increase in the cost of collecting conventional taxes. The following proposition addresses this case.

Proposition 3 (Time-varying $k$ ) Consider a perfect foresight equilibrium path for an arbitrary path of $\left\{k_{t}\right\}_{t=0}^{\infty}$. If along such a path, $k_{t+1}>k_{t}$ for any $t$, then $I_{t+1}>I_{t}$ and $\theta_{t+1}<\theta_{t}$.

\section{Proof. See Appendix.}

Proposition 3 - illustrated by the full line paths in Figure 11 - says that in periods in which collection costs are higher, then the inflation tax will be higher and the consumption tax will be lower. ${ }^{43}$ Intuitively, a higher $k$ makes the consumption tax more costly to collect, which induces the government to switch from taxing consumption to taxing real money balances. Revenues from the consumption tax therefore fall during high- $k$ periods. As shown in the Appendix, total tax revenues also fall, reflecting the fact that it is relatively inefficient to raise revenues while $k$ is high.

Notice that Proposition 3 could explain a situation in which the rate of inflation is positive during wartime and negative (i.e., deflation) during peacetime in such a way that the average inflation rate is zero. To see this, recall that $I=\frac{i}{1+i}$ and $1+i=(1+r)(1+\pi)$. Hence, a zero inflation rate (i.e., $\left.\pi=0\right)$ implies a positive inflation $\operatorname{tax}\left(I=\frac{r}{1+r}\right)$. A low peacetime value of $k$ could imply that the optimal peacetime inflation tax is less than $\frac{r}{1+r}$, so that the optimal peacetime inflation rate is negative. During wars, the optimal inflation tax could be greater than $\frac{r}{1+r}$, which implies a positive inflation rate.

\subsection{Costly borrowing}

Up to now we have assumed that there is perfect capital mobility; that is, the government can borrow as much as it wants - subject of course to its intertemporal constraint - at a constant international interest rate, $r$, without incurring in additional costs. We have thus assumed away any possible imperfection in international capital markets. In reality, it is rarely possible for countries to maintain full access to international capital markets during wartime, without having to pay a higher real interest rate or incurring in some other costs. This may reflect a risk premium or, more generally, an unwillingness of international lenders to provide funds without additional guarantees.

To capture such a situation in a simple way, it will be assumed that the government faces some borrowing costs which are not captured directly in the

\footnotetext{
${ }^{43}$ In Figure 11, $g_{t}$ is also shown to be high between $T$ and $T^{*}$ because, as argued in the next section, we associate higher collection cost with wars. Formally, however, it should be clear that the path of $g_{t}$ is irrelevant for the results.
} 
real interest rate charged by international lenders. These costs - which, in a slight abuse of language, will be referred to as a "risk premium" - are assumed to be an increasing function of the primary deficit. ${ }^{44}$ Notice that for a given level of debt at the beginning of a period, the amount of borrowing needed is an increasing function of the primary deficit. Hence, this formulation captures the idea that having to borrow a large amount of funds in an emergency increases borrowing costs. ${ }^{45}$ Formally, the risk premium, $\Psi$, is assumed to be a strictly increasing and strictly convex function of the primary deficit:

$$
\Psi=f(\delta), \quad f^{\prime}(\delta)>0, f^{\prime \prime}(\delta)>0
$$

where

$$
\delta_{t} \equiv g_{t}-\left(1-k_{t} \theta_{t} c_{t}\right) \theta_{t} c_{t}-I_{t} X_{t} c_{t}\left(1+\theta_{t}\right)
$$

is the primary deficit. ${ }^{46}$ Hence, the larger the borrowing needs in any given period, the larger the associated risk premium.

The government's budget constraint in this case is given by

$$
b_{t}=(1+r) b_{t-1}+\left(1-k_{t} \theta_{t} c_{t}\right) \theta_{t} c_{t}+I_{t} X_{t} c_{t}\left(1+\theta_{t}\right)-g_{t}-f\left(\delta_{t}\right)
$$

As in the previous case, the government maximizes (5) subject to (29) with $\theta_{t}$ and $I_{t}$ given by (14) and (15). The first-order conditions for this problem imply (24) and

$$
\begin{aligned}
\frac{1}{c_{t}} & =-\gamma\left[1+f^{\prime}\left(\delta_{t}\right)\right] \Gamma_{c}\left(c_{t}, X_{t}\right), \\
\gamma\left[1+f^{\prime}\left(\delta_{t}\right)\right] \Gamma_{X}\left(c_{t}, X_{t}\right) & =0
\end{aligned}
$$

where $\Gamma_{c}\left(c_{t}, X_{t}\right)$ continues to be given by (26). ${ }^{47}$ As the right hand side of (30) makes clear, the presence of a risk premium has the effect of rendering more costly, at the margin, the fiscal costs of an additional unit of consumption. In addition to leading to a lower consumption tax and hence lower consumption

\footnotetext{
${ }^{14}$ An alternative way to proceed - but less clean from an aualytical point of view - would be to assume that the real interest rate faced by the country is an increasing function of the stock of debt.

${ }^{45}$ This formulation is based on Talvi and Vegh (1997), who introduce a political distortion whereby government spending is an increasing function of the primary surplus - in an optimal taxation model and show that optimal taxes are procyclical (i.e., taxes are raised in bad times and lowered in good times).

${ }^{46}$ Since it is inconsequential for our results, we do not take a stand on the values of $\delta$ for which $f($.$) is a positive function. The function f($.$) could thus be negative for \delta<0$. The important assumption about $f($.$) is that it be strictly increasing and convex.$

${ }^{47} \mathrm{As}$ in the previous case, the second-order conditions imply that, at an optimum, $\Gamma_{c}<0$, and hence, by $(30), \gamma>0$. By (31), this implies that, at an optimum, $\Gamma_{X}=0$.
} 
tax revenues, an additional unit of consumption increases the primary deficit and thus the associated risk premium.

To isolate the effects of the risk premium, the parameter $k$ will be assumed to be positive but constant over time (as in Proposition 2) We can then show the following:

Proposition 4 Suppose that $k_{t}=k>0$. In the presence of a risk premium, the government increases both the infiation tax and the consumption tax in periods of high expenditure.

\section{Proof. See Appendix.}

The remarkable implication of facing a risk premium is that, even if collection costs do not increase during wars, the government finds it optimal to increase both taxes. Intuitively, consider a period of high government expenditures. If the government kept taxes unchanged, the primary deficit would rise one-forone with the higher expenditures and thus increase the risk premium. It thus proves optimal for the government to raise taxes and reduce to some extent the primary deficit in order to lower the risk premium entailed by the fresh borrowing.

It should be noticed that a positive $k$ is a critical assumption for the inflation tax to go up during times of high government spending. As follows from (24) and Proposition 1, if $k=0$, then the inflation tax would always be zero regardless of the path of government spending. In that case, it can be shown that in times of high government spending only the consumption tax would be raised. In contrast, when $k>0$, the rise in the consumption tax increases, other things being equal, the marginal collection costs of the consumption tax. This makes it optimal for the government to increase the inflation tax as well. Hence, positive collection costs are an essential ingredient for the inflation tax to rise during periods of high expenditure. As in the case of Proposition (3), this scenario could also explain inflation during wartime and deflation during peacetime.

\subsection{Non-costly unexpected inflation}

As discussed above, both Proposition 3 and 4 could in principle explain a situation in which the inflation rate is higher during wartime but is still zero on average, so that the price level exhibits mean reversion. This requires, of course, either that collection costs increase during wars (Proposition 3) or imperfect access to capital markets (Proposition 5). We now consider yet another variation of the model intended to convey the basic intuition behind a result derived by Calvo and Guidotti (1993) in a stochastic setting, which suggests another scenario in which the inflation rate could rise during wars and still be zero on average. Although under perfect certainty the assumptions may seem somewhat extreme, this case provides the basic intuition for understanding the result in a stochastic environment. 
Consider the case studied in Proposition 2, in which collection costs are constant. Suppose further that the government cannot issue any debt (i.e., it cannot borrow either domestically or internationally). In other words, the government must finance all current expenditures with current revenues. Suppose, further, that the government can resort to a lump-sum tax subject to the restriction that the present discounted value of the revenues collected with such a lump-sum tax must be zero. Hence, the government can resort, as before, to the consumption and inflation taxes and, in addition, to this lump-sum tax. Then, we can show the following result:

Proposition 5 (Zero-revenue, lump-sum tax available) Let $k_{t}=k>0$. Suppose that the government cannot borrow but has available a lump-sum tax which, on average, cannot collect any revenues. The optimal policy then consists in financing permanent government spending with the consumption tax and the inflation tax, and finance all deviations of permanent spending from current spending by using the lump-sum tax.

Proof. See Appendix.

The intuition behind this result is simple enough. By definition, the deviations of current government spending from permanent government spending have a present discounted value of zero. By using the lump-sum tax to finance such deviations, the government reproduces the solution under Proposition 2. The fact that it cannot borrow during bad times and lend during good times is not a binding constraint because by lump-sum taxing households in bad times and giving them subsidies in good times, it can achieve the same equilibrium.

Let us now consider the stochastic case studied by Calvo and Guidotti (1993). Assume the following: (i) government spending is stochastic (i.i.d); (ii) the government cannot issue state-contingent debt, and (iii) households decide how much real money balances to hold before the state of nature is revealed. Then, it is clear that unanticipated inflation will have no welfare costs, as it acts precisely as a lump-sum tax because it does not affect decisions. Of course, expected inflation has welfare costs. The optimal policy, as shown by Calvo and Guidotti (1993), is then to set conventional taxes so as to finance the expected value of government spending and use unanticipated inflation to finance all the unanticipated variability in government spending.

The logic behind this result follows from Proposition 5. In this case, the government cannot issue state-contingent debt and hence is precluded from using debt to keep taxes constant when government spending rises unexpectedly. But it can resort to a lump-sum tax (unanticipated inflation) - which does not collect any revenue on average - to finance these unanticipated changes. By so doing, it reproduces the equilibrium that would obtain if it could issue state contingent debt.

Since the government generates unanticipated inflation to finance unexpected changes in government spending, the actual path of inflation will rise during wartime and fall during peacetime. In fact, if $k$ were such that expected inflation is zero (i.e., $I=\frac{r}{1+r}$ ), then the model predicts positive inflation during wars and deflation during peacetime, as illustrated in Figure 13. 


\section{The United States and Argentinean experi- ences: An interpretation}

The propositions derived from the model in Section 5 can be applied to the historical experiences of the two countries. For the United States, with the exception of the War of Independence, wars were mainly financed by debt. In addition, wartime debt was completely retired in the subsequent peacetime periods (Figure 8). In this sense, the perfect tax-smoothing case of Proposition 1 would suit the United States, as argued earlier by Barro $(1979,1986) .{ }^{48}$ However, the fact that the inflation tax was also used during all major wars suggests that collection costs might have been a factor, so that Proposition 2 would apply instead. Proposition 2 would imply, however, that inflation on average should be positive, which was not the case for the United States since the price level in 1900 was virtually the same as in 1774 (Figure 6). Hence, to explain the case of the United States, we need a scenario which calls for inflation during wars and deflation during peacetime so that the average inflation rate is zero. As discussed in the previous section, such a prediction could result from Propositions 3, 4, and 5 (in the Calvo and Guidotti (1993) interpretation).

As argued below, our reading of the historical evidence suggests that the United States did not appear to have faced special difficulties raising tax revenues during wars (i.e., Proposition 3 would not apply), nor did it face higher borrowing costs during wars (i.e., Proposition 4 would not apply either). This suggests to us that Proposition 5 - reinterpreted along the lines of Calvo and Guidotti (1993) - may be the relevant one for the United States: unanticipated inflation finances the unanticipated component of temporary government expenditures and, on average over the whole period, the government does not collect any revenues from the inflation tax. In fact, if $k$ were positive but small, the expected inflation rate would be close to zero. Actual inflation, however, would be positive during wars and negative in peacetime. In sum, proposition 5 with a small $k$ would seem to provide a good fit for the United States pattern since it implies that wars should be financed by debt and inflation, followed by debt retirement and deflation.

For Argentina, the perfect tax-smoothing case with no inflation tax (Proposition 1) definitely does not apply. Debt was never completely retired in peacetime. Nor would Proposition 5 apply because wartime inflation was not offset by deflation (Figures 1 and 2). The Argentinean case, we conjecture, is a combination of Propositions 3 and 4. On the one hand, because of high collection costs - which increased as wartime blockades reduced the primary source of tax revenues, trade taxes - the composition of tax revenues changed towards an increased use of the inflation tax during wartime, as Proposition (3) would imply. On the other hand, having defaulted on its external debt in 1827, Argentina faced increasing costs of borrowing abroad, thus forcing it to rely more on taxes during wars, as Propositon 4 suggests.

\footnotetext{
${ }^{48}$ Later on, World War II would also be financed mainly by issuing debt. The Korean War, however, was financed primarily by higher taxes (see Ohanian (1998)).
} 
We have thus argued that, given the type of constraints assumed in the theoretical section, the outcome in Argentina and the United States can be viewed as the optimal policy response from a public finance perspective. Several factors could explain the different constraints faced by the two countries.

1. Unlike the United States, Argentina was in an almost perpetual state of war. Both countries in their formative years faced large wars which represented a serious threat to their sovereignty. The United States fought the War of Independence (1775-1783), the War of 1812 (1812-1815), and the Civil War (1861-1865). ${ }^{49}$ On the other hand, Argentina fought its wars of Independence from 1810-1821, the war with Brazil (1825-1828), the French Blockade (1838-1840), and the Anglo-French blockade (18451847). However, unlike the United States for whom wars were punctuated by long periods of peace, Argentina's foreign altercations occurred within a background of perpetual civil war.

2. Tax structures were similar but revenue collected differed. Although the United States in the eighteenth century faced a serious deficiency in raising sufficient revenues to finance normal government expenditures and, especially, war-time expenditures, by 1790 the Congress had the power to raise sufficient tax revenues to service its debt and to cover normal peacetime expenditures (see Figure 10). The sources of tax revenues import tariffs, excise taxes, and revenues from land sales - only had to be supplemented by an emergency income tax during the American Civil War. By contrast, Argentina, although with a fairly similar tax structure (Argentina's principal sources of revenue were trade taxes supplemented by excise taxes), the revenues collected were vastly different. In Argentina, trade tax revenues declined drastically in every serious wartime episode which involved blockades (see Table 1). As a consequence, revenues in Argentina were both lower and more variable.

3. Unlike the United States, Argentina found it increasingly difficult to rely on long-term bond financing. Both countries had trouble in selling longterm bonds at favorable rates during wartime. But the contrast between the two countries is quite stark. In the American revolutionary war, the government was forced to finance 85 percent of its expenditures with the inflation tax, but for the two later major wars of the nineteenth century its credibility had improved to the point where it financed the majority of its expenditure by bond sales. In contrast, Argentina was able to finance most of the War of Independence with debt issue (including forced loans), but for the later conflicts it could only rely to a very minor extent on this form of finance. The reason for this different access to bond-financing was that, after its three wars, the United States raised sufficient tax revenues to effectively service its debt and even retire it in large part. This, however,

${ }^{49}$ We do not attach much importance to the frequent Indian wars and to the war with Mexico (1846-1848) and with Spain (1898). 
was not the case for Argentina which defaulted on its foreign debt in 1827 and had difficulties servicing its domestic debt during many years. Several attempts in Argentina to undertake American- style funding operations and establishing sinking funds failed $(1821,1829,1833)$. This state of affairs would tend to support the assumption of costly borrowing in Section 5 .

4. Unlike in the United States, the banks of issue in Argentina quickly departed from their original intent. As in the case of the First and Second Banks of the United States, the original intent of the founders of the Banco de Buenos Aires in 1822 was to establish a bank which would aid the government in funding its debt and provide credit to the private sector, while maintaining the convertibility of its notes in gold. However, faced with the constraints of war finance discussed above, this bank and its successors quickly became financial agents of the treasury by printing inconvertible paper-money. In the United States, until the creation of Federal Reserve in 1914, banks of issue were not explicitly used for this purpose.

5. Political forces in Argentina tended to reinforce and perpetuate fiscal constraints. In Argentina, the relaxation of the constraints examined above related to the tax structure and debt financing was made more difficult by the presence of dominant political groups who benefitted from inflationmainly cattle-ranchers who profited from the ensuing real depreciation. These groups would oppose raising conventional taxes to retire either debt or notes issue, since they viewed inflation as a more convenient way (from their perspective) of raising revenue. By contrast, prevailing political forces in the United States did not greatly benefit from inflation and thus did not oppose the use of debt and taxes to finance public spending.

\section{Conclusions}

The contrast between the early nineteenth century Argentinean experience of high inflation and the United States experience of low inflation has been interpreted in terms of a dynamic optimal taxation model. The two countries' experiences differ because of the different constraints they faced in financing government wartime expenditures. In the presence of frequent wars and facing ever-tightening access to foreign capital and an inadequate tax base, Argentina used the inflation tax as an efficient solution to its wartime problem. By contrast, the United States, after its Revolutionary War, retired its outstanding debt and, under Alexander Hamilton's tutelage, set up fiscal institutions which allowed it to bond-finance most subsequent wartime expenditures and use the inflation tax only on a temporary basis. In peacetime, debt retirement and deflation ensured continuous access to tax-smoothing in the event of future wars.

To isolate the different wartime fiscal strategies used by the two nations, we model the constraints that they faced as purely exogenous. In reality, such constraints should not be viewed as strictly exogenous. Argentina faced increasing 
problems in accessing world capital markets because of its earlier default and its unwillingness to take the steps necessary to restore credibility. It had an inadequate tax structure because of the emphasis on trade taxes which were subject to disruption in periods of war. Both constraints prevailed because of the unwillingness of the dominant political group, the ranchers, to allow themselves to be taxed. By contrast, in the United States these constraints were avoided because of the recognition of Hamilton and others of the importance of sound public finance (embodied in a long-term bond market, sinking fund, national bank of issue, and adequate tax base) for future wartime finance, attracting foreign capital, and economic development. Imbedding these political economy considerations into a public finance model-albeit a potentially difficult analytical task--should add interesting insights to our understanding of inflationary finance.

In sum, faced with formidable constraints and political forces opposed to dealing with them, it is doubtful that had Alexander Hamilton been an Argentinean the inflationary outcome in Argentina would have been much different.

\section{References}

[1] Ahmed, Shaghil, "Temporary and Permanent Government Spending in an Open Economy" Journal of Monetary Economics, Vol. 17 (1986), pp. 197224.

[2] Alberdi, Juan Bautista, Estudios Economicos (Montevideo: Fundacion Prudencio Vazquez y Vega, 1989).

[3] Alemann, Roberto, Breve Historia de la Politica Economica Argentina: 1500-1989 (Buenos Aires: Editorial Claridad, 1989).

[4] Auernheimer, Leonardo, "The Honest Government's Guide to the Revenue from Money Creation," Journal of Political Economy, Vol. 82 (1974), pp. 598-606.

[5] Barro, Robert J., "On the Determination of the Public Debt," Journal of Political Economy, Vol. 87 (1979), pp. 940-971.

[6] Barro, Robert J., "U.S. Deficits since World War I," Scandinavian Journal of Economics, Vol. 88 (1986), pp. 195-222.

[7] Barro, Robert J., "Government Spending, Interest Rates, Prices, and Budget Deficits in the United Kingdom, 1701-1918," Journal of Monetary Economics, Vol. 20 (1987), pp. 221- 247.

[8] Bordo, Michael D. and Anna J. Schwartz, "The Operation of the Specie Standard: Evidence from Core and Peripheral Couuntries, 1880-1990," in Jorge Braga de Macedo, Barry Eichengreen, and Jaime Reis, eds., Currency Convertibility: The Gold Standard and Beyond (New York: Routledge, 1996). 
[9] Burgin, Miron, The Economic Aspects of Argentine Federalism, 1820-1852 (Cambridge, Massachusetts: Harvard University Press, 1946).

[10] Calomiris, Charles W., "Institutional Failure, Monetary Scarcity, and the Depreciation of the Continental," Journal of Economic History, Vol. XLVIII (1988), pp. 47-68.

[11] Calvo, Guillermo A., "On the Time Consistency of Optimal Policy in a Monetary Economy," Econometrica, Vol. 46 (1978), pp. 1411-28.

[12] Calvo, Guillermo A., and Pablo E. Guidotti, "On the Flexibility of Monetary Policy: The Case of the Inflation Tax," Review of Economic Studies, Vol. 60 (1993), pp. 667-687.

[13] Cortés Conde, Roberto, El Progreso Argentino: 1880-1914 (Buenos Aires: Editorial Sudamericana, 1979).

[14] Cortés Conde, Roberto, Dinero, Deuda y Crisis (Buenos Aires: Editorial Sudamericana, 1989).

[15] Cortés Conde, Roberto, and George McCandless, "Argentina: From Colony to Nation-XVIII and XIX Centuries," mimeo (Universidad de San Andrés, 1997).

[16] David, Paul A., and Peter Solar, "A Bicentary Contribution to the History of the Cost of Living in America," Research in Economic History (1977), pp. $1-80$.

[17] Della Paolera, Gerardo, "Monetary and Banking Experiments in Argentina: 1861-1930," mimeo, Universidad Torcuato di Tella (1995).

[18] Della Paolera, Gerardo, and Alan Taylor, "Finance and Development in an Emerging Market: Argentina in the Interwar Period," NBER Working Paper No. 6236 (1997).

[19] Della Paolera, Gerardo, and Alan Taylor, "Economic Recovery from the Argentine Great Depression: Institutions, Expectations, and the Change of Macroeconomic Regime," mimeo (Northwestern University and Universidad Torcuato Di Tella, 1998).

[20] Dewey, Davis R., Financial History of the United States (New York: Longmens Green, 1920).

[21] Di Tella, Guido and Rudiger Dornbusch, The Political Economy of Argentina, 1946-83 (Pittsburgh: The University of Pittsburgh Press, 1989).

[22] Difrieri, Jorge A., Moneda y Bancos en la Republica Argentina (Buenos Aires: Abeledo- Perrot, 1967). 
[23] Dixit, Avinash, "The Optimal Mix of Inflationary Finance and Commodity Taxation with Collection Lags," IMF Staff Papers, Vol. 38 (1991), pp. 643654 .

[24] Friedman, Milton, "Price, Income, and Monetary Changes in Three Wartime Periods," American Economic Review, Papers and Proceedings, Vol. 42 (1952), pp. 612-625.

[25] Friedman, Milton and Anna J. Schwartz, A Monetary History of the United States, 1867- 1960 (Princeton: Princeton University Press, 1963).

[26] Friedman, Milton, and Anna Schwartz, Monetary Statistics of the United States (New York: Columbia University Press, 1970).

[27] Friedman, Milton, and Anna Schwartz, Monetary Trends in the United States and United Kingdom (Chicago: University of Chicago Press, 1982).

[28] Garber, Peter, "Alexander Hamilton's Market-Based Debt Reduction Plan," Carnegie Rochester Conference Series on Public Policy, Vol. 35 (Autumn 1991), pp. 79-104.

[29] Grossman, Herschel I., and Taejoon Han, "War Debt, Moral Hazard, and the Financing of the Confederacy," Journal of Money, Credit and Banking, Vol. 28 (1996), pp. 200-215.

[30] Hansen, Emilio, La Moneda Argentina (Buenos Aires: Ramon Sopena, 1916).

[31] Kimbrough, Kent, "The Optimum Quantity of Money Rule in the Theory of Public Finance," Journal of Monetary Economics, Vol. 18 (1986), pp. 277-284.

[32] Lerner, Eugene, "Inflation in the Confederacy, 1861-65," in Milton Friedman, ed., Studies in the Quantity Theory of Money (Chicago: University of Chicago Press, 1956).

[33] Lucas, Robert E., Jr., and Nancy Stokey, "Optimal Fiscal and Monetary Policy in an Economy without Capital," Journal of Monetary Economics, Vol. 12 (1983), pp. 55-93.

[34] Macesich, George, "Sources of Monetary Disturbances in the United States, 1834-45," Journal of Economic History, Vol. 20 (1960), pp. 407-434.

[35] McCallum, Bennett T., Monetary Economics: Theory and Policy (New York: McMillan Press, 1989).

[36] McCallum, Bennett T., "Money and Prices in Colonial America: A New Test of Competing Theories," Journal of Political Economy, Vol.100 (1992), pp. 143-161. 
[37] Michener, Ronald, "Fixed Exchange Rates and the Quantity Theory in Colonial America," Carnegie Rochester Conference Series on Public Policy, Vol. 27 (1987), pp. 233-307.

[38] Mulligan, Casey and Xavier Sala-i-Martin, "The Optimum Quantity of Money: Theory and Evidence," mimeo (University of Chicago and Columbia University, 1997).

[39] Officer, Lawrence H., "Dollar-Sterling Mint Parity and Exchange Rates, 1791-1834," Journal of Economic History, Vol. XLIII (1983), pp. 579-616.

[40] Officer, Lawrence H., "Integration in the American Foreign-Exchange Market, 1791-1900," Journal of Economic History, Vol. XLV (1985), pp. 557585 .

[41] Ohanian, Lee, "The Macroeconomic Effects of War Finance in the United States," American Economic Review (1998), forthcoming.

[42] Perkins, Edwin J., American Public Finance and Financial Services, 17001815 (Columbus, Ohio: Ohio State University Press, 1994).

[43] Phelps, Edmund, "Inflation in the Theory of Public Finance," Swedish Journal of Economics, Vol. 75 (1973), pp. 67-82.

[44] Redish, Angela, "Why Was Specie Scarce in Colonial Economies? An Analysis of the Canadian Currency, 1796-1830," Journal of Economic History, Vol. XLIV (1984), pp. 713- 728.

[45] Rock, David, Argentina 1516-1987: From Spanish Colonization to Alfonsin (Berkeley and Los Angeles: University of California Press, 1987).

[46] Smith, Bruce, 1985a, "American Colonial Monetary Regimes: The Failure of the Quantity Theory and Some Evidence in Favor of an Alternative View," Canadian Journal of Economics, Vol. 18 (1985), pp. 531-565.

[47] Smith, Bruce, 1985b, "Some Colonial Evidence on Two Theories of Money: Maryland and the Carolinas," Journal of Political Economy, Vol. 93 (1985), pp. 1178-1211.

[48] Talvi, Ernesto and Carlos A. Végh, "Can Optimal Fiscal Policy Be Procyclical?," unpublished manuscript (CERES, Uruguay, and UCLA, 1997)

[49] Temin, Peter, The Jacksonian Economy (New York: W.W. Norton, 1969).

[50] Timberlake, Richard, Monetary Policy in the United States: An Intellectual and Institutional History (Chicago: University of Chicago Press, 1993).

[51] Unger, Irwin, The Greenback Era: A Social and Political History of American Finance, 1865-1879 (Princeton: Princeton University Press, 1964). 
[52] United States Department of Commerce, Historical Statistics of the United States (1976).

[53] Végh, Carlos A., "Government Spending and Inflationary Finance: A Public Finance Framework," IMF Staff Papers, Vol. 36 (1989), pp. 657-677.

[54] Végh Villegas, Alejandro, "El Pensamiento Economico de Alberdi," prologue to Juan Bautista Alberdi, Estudios Economicos (Montevideo: Fundacion Prudencio Vazquez y Vega, 1989), pp. 19-34. 


\section{Appendix}

Proof of Proposition 1. If $k_{t}=0$, it follows from (24) that

$$
-v^{\prime}\left(X_{t}\right)-\frac{v^{\prime \prime}\left(X_{t}\right) X_{t} v\left(X_{t}\right)}{1+v\left(X_{t}\right)-v^{\prime}\left(X_{t}\right) X_{t}}=0 .
$$

Taking into account (3), it follows that $X=X^{s}$ satisfies this equation. In fact, $X^{s}$ is the only value of $X$ that satisfies equation (32), since the LHS is a strictly decreasing function of $X$. Hence, $I=0 .{ }^{50}$ From (23) with $k=0$, it follows that $c_{t}$ is constant along a PFEP. Therefore, from (6), so is $\theta_{t}$. Assuming, for simplicity, that $b_{-1}=f_{-1}+z_{-1}=0$, then $\theta=\bar{g} /(1 / 2-\bar{g})$, where $\bar{g}$ denotes permanent government spending.

Proof of Proposition 2. We first show that if $k_{t}=k>0$, then $1-2 k \theta_{t} c_{t}$ is also constant over time. The proof proceeds by contradiction. Suppose $1-2 k \theta_{t} c_{t}$ were not constant. We need to consider two cases.

(i) Suppose that, for some $t, 1-2 k \theta_{t+1} c_{t+1}>1-2 k \theta_{t} c_{t}$. Hence, $\theta_{t+1} c_{t+1}<$ $\theta_{t} c_{t}$. The fact that $k \theta_{t+1} c_{t+1}<k \theta_{t} c_{t}$ also implies that $X_{t+1}>X_{t}$ since equation (24) implicitly defines a strictly inverse relationship between $X$ and $k \theta c$. Hence, from (6), $c_{t+1}\left(1+\theta_{t+1}\right)>c_{t}\left(1+\theta_{t}\right)$ and thus, $c_{t+1}>c_{t}$. But this contradicts (23) since the left hand side falls while the right hand side increases.

(ii) Suppose that, for some $t, 1-2 k \theta_{t+1} c_{t+1}<1-2 k \theta_{t} c_{t}$. Hence, $\theta_{t+1} c_{t+1}>$ $\theta_{t} c_{t}$. The fact that $k \theta_{t+1} c_{t+1}>k \theta_{t} c_{t}$ also implies that $X_{t+1}<X_{t}$ since equation (24) implicitly defines a strictly inverse relationship between $X$ and $k \theta c$. Hence, from (6), $c_{t+1}\left(1+\theta_{t+1}\right)<c_{t}\left(1+\theta_{t}\right)$ and thus, $c_{t+1}<c_{t}$. But this contradicts (23) since the left hand side increases while the right hand side falls.

We have thus shown that if, along a PFEP, $k_{t}=k>0$, then $1-2 k \theta_{t} c_{t}$ is also constant. This implies that $\theta_{t} c_{t}$ is constant over time. Hence, from (24), $X_{t}$ is constant over time, which implies from (6) that $c_{t}\left(1+\theta_{t}\right)$, and hence $c_{t}$ are constant over time. It follows that both $\theta_{t}$ and $I_{t}$ are constant over time.

Having established that taxes are constant along a PFEP, we now establish that they both will be positive. First notice that $\theta$ cannot be zero. For, if it were, it follows from (24), that $I=0$. But since permanent government spending is positive, both taxes cannot be zero. Hence, $\theta>0$. Then, from (24), it follows that $X<X^{s}$ and therefore, from (8), $I>0$.

Proof of Proposition 3. We first show that if, for some $t, k_{t+1}>k_{t}$, then $1-2 k_{t+1} \theta_{t+1} c_{t+1}<1-2 k_{t} \theta_{t} c_{t}$. The proof proceeds by contradiction. Suppose $1-2 k_{t+1} \theta_{t+1} c_{t+1} \nless 1-2 k_{t} \theta_{t} c_{t}$. We need to consider two cases.

(i) Suppose that $1-2 k_{t+1} \theta_{t+1} c_{t+1}=1-2 k_{t} \theta_{t} c_{t}$. This implies that $k_{t+1} \theta_{t+1} c_{t+1}=k_{t} \theta_{t} c_{t}$ and thus that $\theta_{t+1} c_{t+1}<\theta_{t} c_{t}$. Since $k_{t+1} \theta_{t+1} c_{t+1}=$ $k_{t} \theta_{t} c_{t},(24)$ implies that $X_{t+1}=X_{t}$. Hence, from (6), $\left(1+\theta_{t+1}\right) c_{t+1}=\left(1+\theta_{t}\right) c_{t}$. Since $\theta_{t+1} c_{t+1}<\theta_{t} c_{t}$, the latter implies that $c_{t+1}>c_{t}$. We have reached a contradiction since (23) is violated as the left hand side falls but the right hand side remains unchanged.

\footnotetext{
${ }^{50}$ In all cases, it can be checked that second-order conditions are satisfied.
} 
(ii) Suppose that $1-2 k_{t+1} \theta_{t+1} c_{t+1}>1-2 k_{t} \theta_{t} c_{t}$. This implies that $k_{t+1} \theta_{t+1} c_{t+1}<k_{t} \theta_{t} c_{t}$ and thus that $\theta_{t+1} c_{t+1}<\theta_{t} c_{t}$. Since $k_{t+1} \theta_{t+1} c_{t+1}<$ $k_{t} \theta_{t} c_{t},(24)$ implies that $X_{t+1}>X_{t}$. Hence, from (6), $\left(1+\theta_{t+1}\right) c_{t+1}>\left(1+\theta_{t}\right) c_{t}$. Since $\theta_{t+1} c_{t+1}<\theta_{t} c_{t}$, the latter implies that $c_{t+1}>c_{t}$. This contradicts (23) as the left hand side falls but the right hand side increases.

We have thus shown that if, along a PFEP, $k_{t+1}>k_{t}$, then $1-2 k_{t+1} \theta_{t+1} c_{t+1}<$ $1-2 k_{t} \theta_{t} c_{t}$. Hence, $k_{t+1} \theta_{t+1} c_{t+1}>k_{t} \theta_{t} c_{t}$. By (24), $X_{t+1}<X_{t}$ and thus, by (8), $I_{t+1}>I_{t}$. Also, since $X_{t+1}<X_{t}$, by (23), $\left(1+\theta_{t+1}\right) c_{t+1}<\left(1+\theta_{t}\right) c_{t}$. But, since $1-2 k_{t+1} \theta_{t+1} c_{t+1}<1-2 k_{t} \theta_{t} c_{t}, c_{t+1}>c_{t}$. Then, $\theta_{t+1} c_{t+1}<\theta_{t} c_{t}$ and thus $\theta_{t+1}<\theta_{t}$.

To find out the effect on total tax revenues, notice that, using (22), we can compute the total differential change in total revenues (taking also in account the change in $k$ ) and evaluate it around an optimum to obtain:

$$
d \Gamma(c, X, k)=\Gamma_{c}(c, X, k) d c+\Gamma_{X}(c, X, k) d X+\Gamma_{k}(c, X, k) d k<0,
$$

since $d c>0$ and $d k>0$ and around an optimum, $\Gamma_{c}(c, X, k)<0, \Gamma_{X}(c, X, k)=$ 0 , and $\Gamma_{k}(c, X, k)<0$. Hence, $\Gamma\left(c_{t+1}, X_{t+1}, k_{t+1}\right)<\Gamma\left(c_{t}, X_{t}, k_{t}\right)$.

Proof of Proposition 4. Consider a PFEP. We first show that if, for some $t, g_{t+1}>g_{t}$, then $X_{t+1}<X_{t}$. The proof proceeds by contradiction. Suppose $X_{t+1} \nless X_{t}$. We need to consider two cases.

(i) Suppose that $X_{t+1}=X_{t}$. This implies that $k \theta_{t+1} c_{t+1}=k \theta_{t} c_{t}$ since equation (24) implicitly defines a strictly inverse relationship between $X$ and $k \theta c$. Hence, $\theta_{t+1} c_{t+1}=\theta_{t} c_{t}$. The fact that $X_{t+1}=X_{t}$ also implies, from (6), that $\left(1+\theta_{t+1}\right) c_{t+1}=\left(1+\theta_{t}\right) c_{t}$. Hence, $c_{t+1}=c_{t}$. It then follows, from (30), that $f^{\prime}\left(\delta_{t+1}\right)=f^{\prime}\left(\delta_{t}\right)$ and, hence, $\delta_{t+1}=\delta_{t}$. But, given that $g_{t+1}>g_{t}$, the latter contradicts (28) since total revenues do not change.

(ii) Suppose that $X_{t+1}>X_{t}$. This implies that $k \theta_{t+1} c_{t+1}<k \theta_{t} c_{t}$ since equation (24) implicitly defines a strictly inverse relationship between $X$ and $k \theta c$. Hence, $\theta_{t+1} c_{t+1}<\theta_{t} c_{t}$. The fact that $X_{t+1}>X_{t}$ also implies, from (6), that $\left(1+\theta_{t+1}\right) c_{t+1}>\left(1+\theta_{t}\right) c_{t}$. Hence, $c_{t+1}>c_{t}$. This, together with the fact that $1-k \theta_{t+1} c_{t+1}>1-k \theta_{t} c_{t}$, implies that $f^{\prime}\left(\delta_{t+1}\right)<f^{\prime}\left(\delta_{t}\right)$ and, hence, $\delta_{t+1}<\delta_{t}$.

Further, since $c_{t+1}>c_{t}$, total revenues fall, as follows from totally differentiating total revenues, given by (22) and evaluating the resulting expression around an optimum:

$$
d \Gamma(c, X, k)=\Gamma_{c}(c, X, k) d c+\Gamma_{X}(c, X, k) d X=\Gamma_{c}(c, X, k) d c<0 .
$$

Hence, $\Gamma\left(c_{t+1}, X_{t+1}\right)<\Gamma\left(c_{t}, X_{t}\right)$.

Since $g_{t+1}>g_{t}$ and $\Gamma\left(c_{t+1}, X_{t+1}\right)<\Gamma\left(c_{t}, X_{t}\right)$, it then follows, from (30), that $\delta_{t+1}>\delta_{t}$, which contradicts our earlier conclusion.

We have thus shown that if, along a PFEP, $g_{t+1}>g_{t}$, for some $t$, then $X_{t+1}<X_{t}$. This implies, from (15) that $I_{t+1}>I_{t}$. Also, from (24), it follows that $k \theta_{t+1} c_{t+1}>k \theta_{t} c_{t}$ and thus $\theta_{t+1} c_{t+1}>\theta_{t} c_{t}$. Also, since $X_{t+1}<X_{t}$, by (23), $\left(1+\theta_{t+1}\right) c_{t+1}<\left(1+\theta_{t}\right) c_{t}$. Hence, $c_{t+1}<c_{t}$. Since $\theta_{t+1} c_{t+1}>\theta_{t} c_{t}$, the 
latter implies that $\theta_{t+1}>\theta_{t}$. Since $1-2 k_{t+1} \theta_{t+1} c_{t+1}<1-2 k_{t} \theta_{t} c_{t}$ and $c_{t+1}<$ $c_{t}$, (23) implies that $f^{\prime}\left(\delta_{t+1}\right)>f^{\prime}\left(\delta_{t}\right)$ and, hence, $\delta_{t+1}>\delta_{t}$.

Proof of Proposition 5. Since the government cannot borrow, it must finance all spending out of current taxes. Further, since the government is contrained not to raise taxes on average with the lump-sum tax, it must finance permanent government spending with distorting taxes. Given that $k_{t}=k>0$, permanent government spending is optimally financed with both the consumption tax and the inflation tax, for the same reasons as in Proposition 2. It is clearly not optimal to finance deviations of current spending from permanent spending with either the consumption or the inflation tax. If that were the case, the effective tax rate would vary over time and households' welfare would be lower. It follows that all fluctuations in spending should be financed with the lump sum tax. 
Table 1. ARGENTINA: Fiscal and Monetary Data, 1820-1861

\begin{tabular}{|c|c|c|c|c|c|c|c|c|c|c|c|}
\hline & \multirow[b]{2}{*}{ Revenues } & \multirow[b]{2}{*}{$\begin{array}{l}\text { Trade } \\
\text { taxes }\end{array}$} & \multirow[b]{2}{*}{ Expend. } & \multirow[b]{2}{*}{ Surplus } & \multirow[b]{2}{*}{$\begin{array}{l}\text { Note } \\
\text { Issue }\end{array}$} & \multicolumn{3}{|c|}{ Cumulative } & \multicolumn{3}{|l|}{ Long Term } \\
\hline & & & & & & $\begin{array}{c}\text { Note } \\
\text { Retired }\end{array}$ & $\begin{array}{c}\text { net } \\
\text { issue }\end{array}$ & $\begin{array}{r}\text { Price of } \\
\text { Gold }\end{array}$ & $\begin{array}{r}\text { Bond } \\
\text { Issues }\end{array}$ & $\begin{array}{l}\text { Amorti } \\
\text { zation }\end{array}$ & $\begin{array}{r}\text { Debt } \\
\text { Outstand. }\end{array}$ \\
\hline 1820 & 1.5 & & 1.5 & 0.0 & & & & & & & \\
\hline 1821 & 2.7 & & 3.3 & -0.6 & & & & & 4.3 & & \\
\hline 1822 & 2.4 & 2.0 & 1.6 & 0.9 & & & & & & & \\
\hline 1823 & 2.0 & & 1.6 & 0.4 & 0.3 & & 0.3 & & 1.8 & & \\
\hline 1824 & 2.6 & 2.0 & 2.7 & 0.0 & 1.4 & & 1.7 & & 0.3 & & \\
\hline 1825 & 2.6 & & 2.9 & -0.2 & 0.3 & & 1.9 & & 0.3 & & \\
\hline 1826 & 1.2 & & 8.0 & -6.8 & 6.0 & 0.9 & 7.0 & 28.8 & & & \\
\hline 1827 & 3.0 & & 9.1 & -6.1 & 2.8 & 0.2 & 9.7 & 56.6 & 6.0 & & \\
\hline 1828 & 3.7 & & 9.3 & -5.7 & 2.8 & & 12.4 & 49.8 & & & \\
\hline 1829 & 7.9 & 6.5 & 9.8 & -1.8 & 2.8 & & 15.2 & 79.7 & & & \\
\hline 1830 & 12.1 & 9.1 & 10.3 & 1.8 & 0.1 & & 15.3 & 117.9 & & & \\
\hline 1831 & 9.0 & 6.2 & 13.3 & -4.3 & & & 15.3 & 111.6 & 6.0 & & \\
\hline 1832 & 10.7 & 7.3 & 12.2 & -1.5 & & & 15.3 & 111.8 & & & \\
\hline 1833 & 12.2 & 9.0 & 12.9 & -0.7 & & & 15.3 & 120.4 & & & \\
\hline 1834 & 12.1 & & 16.5 & -4.4 & & & 15.3 & 118.5 & 8.0 & & \\
\hline 1835 & & & & & & & 15.3 & 118.6 & & 7.1 & 20.3 \\
\hline 1836 & & & & & & & 15.3 & 120.4 & & & \\
\hline 1837 & 17.0 & & 23.8 & -6.8 & 4.2 & & 19.5 & 130.9 & 7.0 & & \\
\hline 1838 & 20.1 & & 20.6 & -0.5 & 16.6 & & 36.0 & 147.0 & & & \\
\hline 1839 & 28.3 & & 28.7 & -0.5 & 3.6 & & 39.7 & 253.9 & & & \\
\hline 1840 & 7.9 & 5.5 & 48.4 & -40.5 & 12.0 & & 51.7 & 374.1 & 10.0 & 2.3 & 36.3 \\
\hline 1841 & 39.3 & 36.4 & 41.7 & -2.4 & 0.0 & & 51.7 & 308.1 & & 2.6 & 33.7 \\
\hline 1842 & 34.1 & 31.4 & 36.3 & -2.2 & 0.0 & & 51.7 & 277.3 & & & 33.7 \\
\hline 1843 & 36.8 & 33.1 & 35.2 & 1.7 & 0.0 & & 51.7 & 350.8 & & & 33.7 \\
\hline 1844 & 32.5 & 29.3 & 34.3 & -1.8 & 0.0 & & 51.7 & 345.0 & & & 33.7 \\
\hline 1845 & 31.5 & 27.8 & 33.9 & -2.4 & 0.0 & & 51.7 & 297.6 & & & 33.7 \\
\hline 1846 & 8.7 & 6.0 & 31.3 & -22.6 & 27.6 & & 79.3 & 242.6 & & 2.9 & 30.8 \\
\hline 1847 & 18.0 & 15.0 & 39.1 & -21.1 & 27.6 & & 106.9 & 265.2 & & 1.0 & 29.8 \\
\hline 1848 & 32.1 & 28.8 & 37.7 & -5.6 & 18.4 & & 125.3 & 224.3 & & 0.2 & 29.6 \\
\hline 1849 & 51.9 & 48.0 & 48.2 & 3.7 & 0.0 & & 125.3 & 241.2 & & 2.4 & 27.1 \\
\hline 1850 & 62.2 & 57.9 & 56.0 & 6.2 & 0.0 & & 125.3 & 362.1 & & 1.1 & 26.0 \\
\hline 1851 & & & & & 0.0 & & 125.3 & 299.5 & & & \\
\hline 1852 & & & & & 23.5 & & 148.8 & 274.2 & & & \\
\hline 1853 & & & & & 67.0 & 7.3 & 208.5 & & & & \\
\hline 1854 & 55.0 & & & & 0.0 & & 208.5 & & & & \\
\hline 1855 & 60.5 & & & & 0.0 & & 208.5 & & & & \\
\hline 1856 & 68.8 & & & & 0.0 & & 208.5 & & & & \\
\hline 1857 & 81.7 & & 87.1 & -5.4 & 0.0 & & 208.5 & & & & \\
\hline 1858 & 74.6 & & 92.0 & -17.4 & 0.0 & & 208.5 & & & & \\
\hline 1859 & 100.8 & & 175.8 & -75.0 & 60.0 & & 268.5 & & & & \\
\hline 1860 & & & & & 25.0 & & 293.5 & & & & \\
\hline 1861 & & & & & 100.0 & 96.8 & 296.7 & & & & \\
\hline
\end{tabular}

Sources: Burgin (1946), Cortes-Conde (1989), and Cortes-Conde and McCandless (1997). 
Figure 1. Argentina: Price of an ounce of gold, 1826-1852

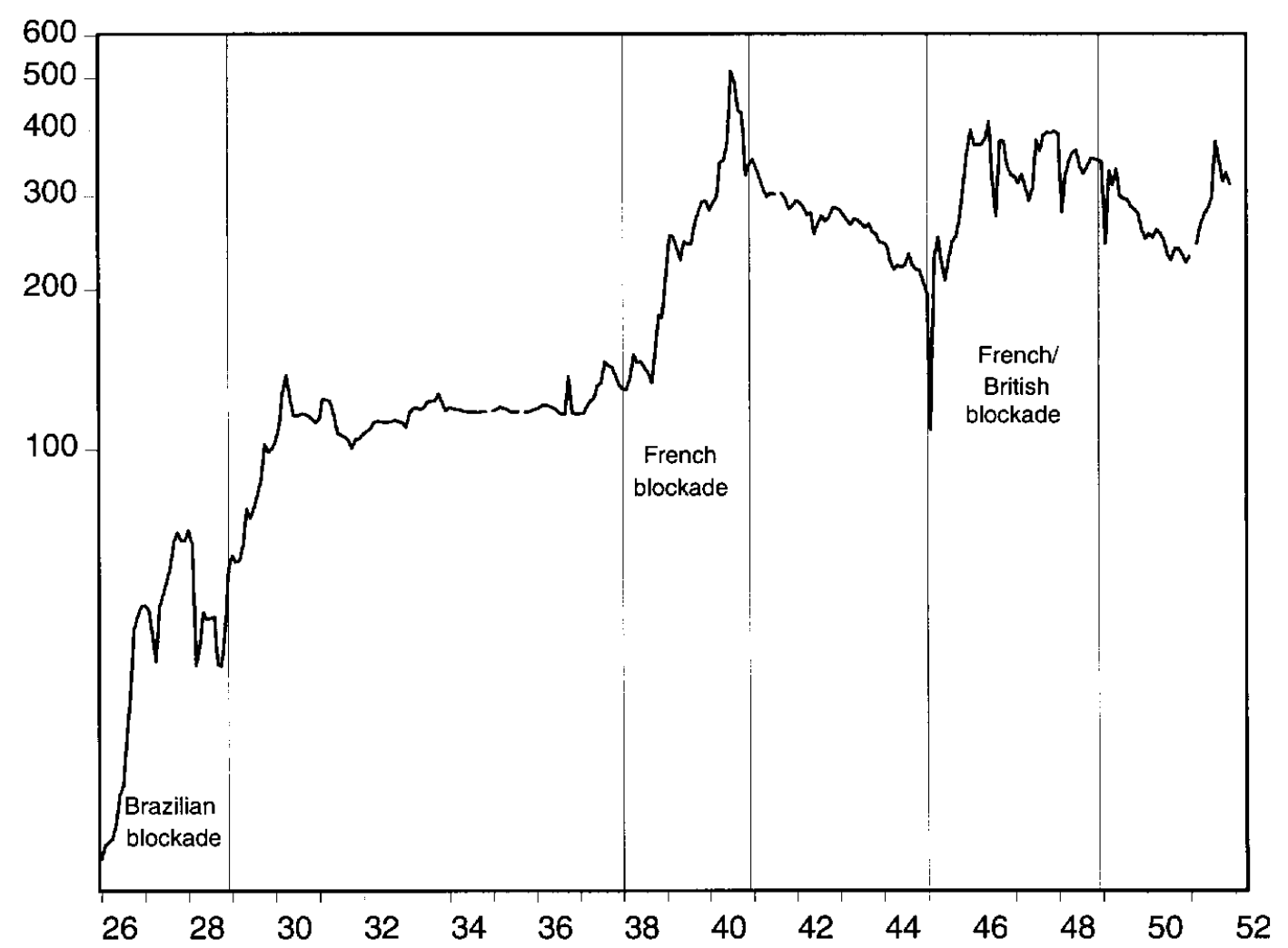

Source: Burgin (1946) 
Figure 2. Argentina: Price level of agricultural products, $1833-1850$

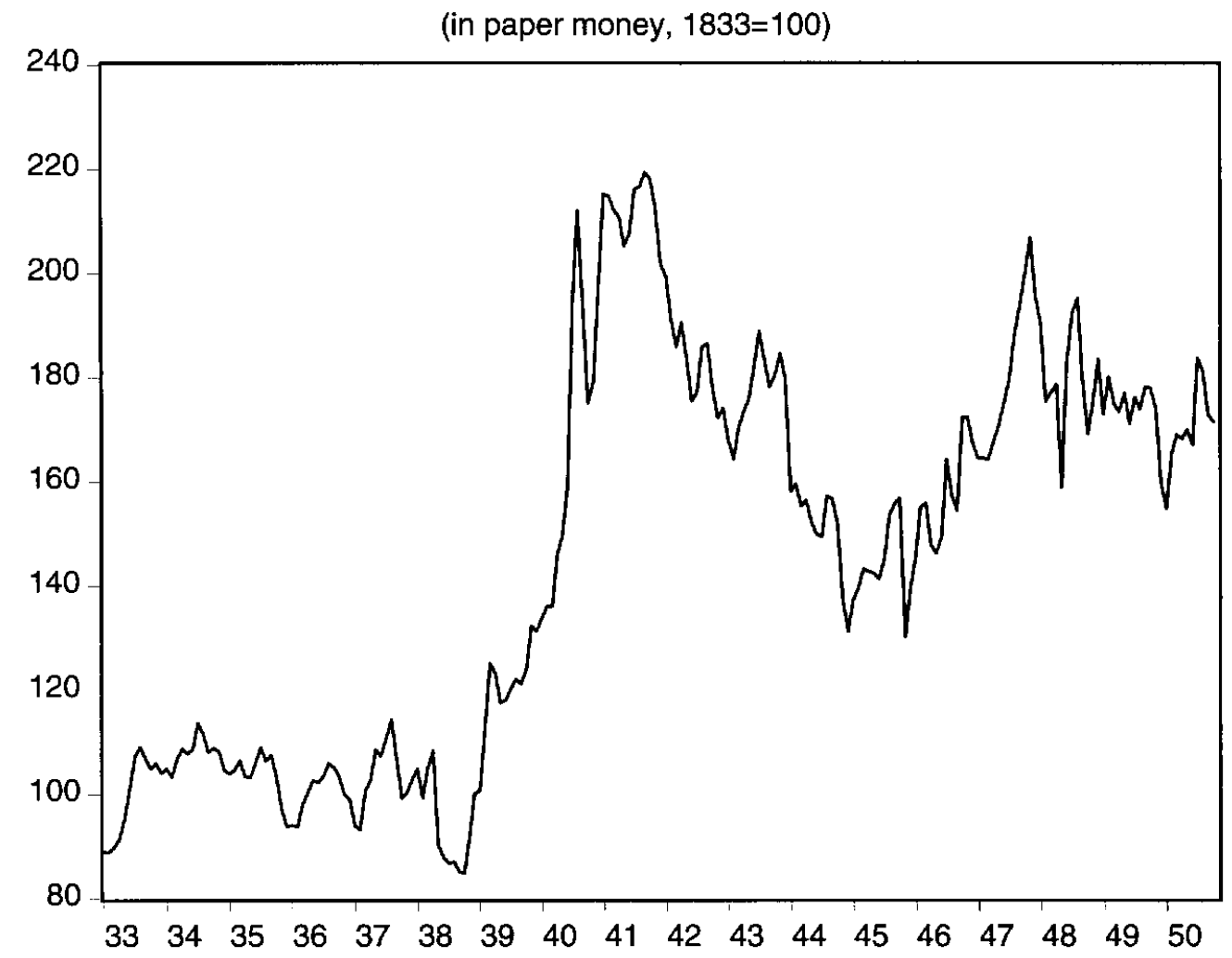

Souce: Data provided by Roberto Cortes Conde 
Figure 3. Argentina: Note issue, 1823-1860

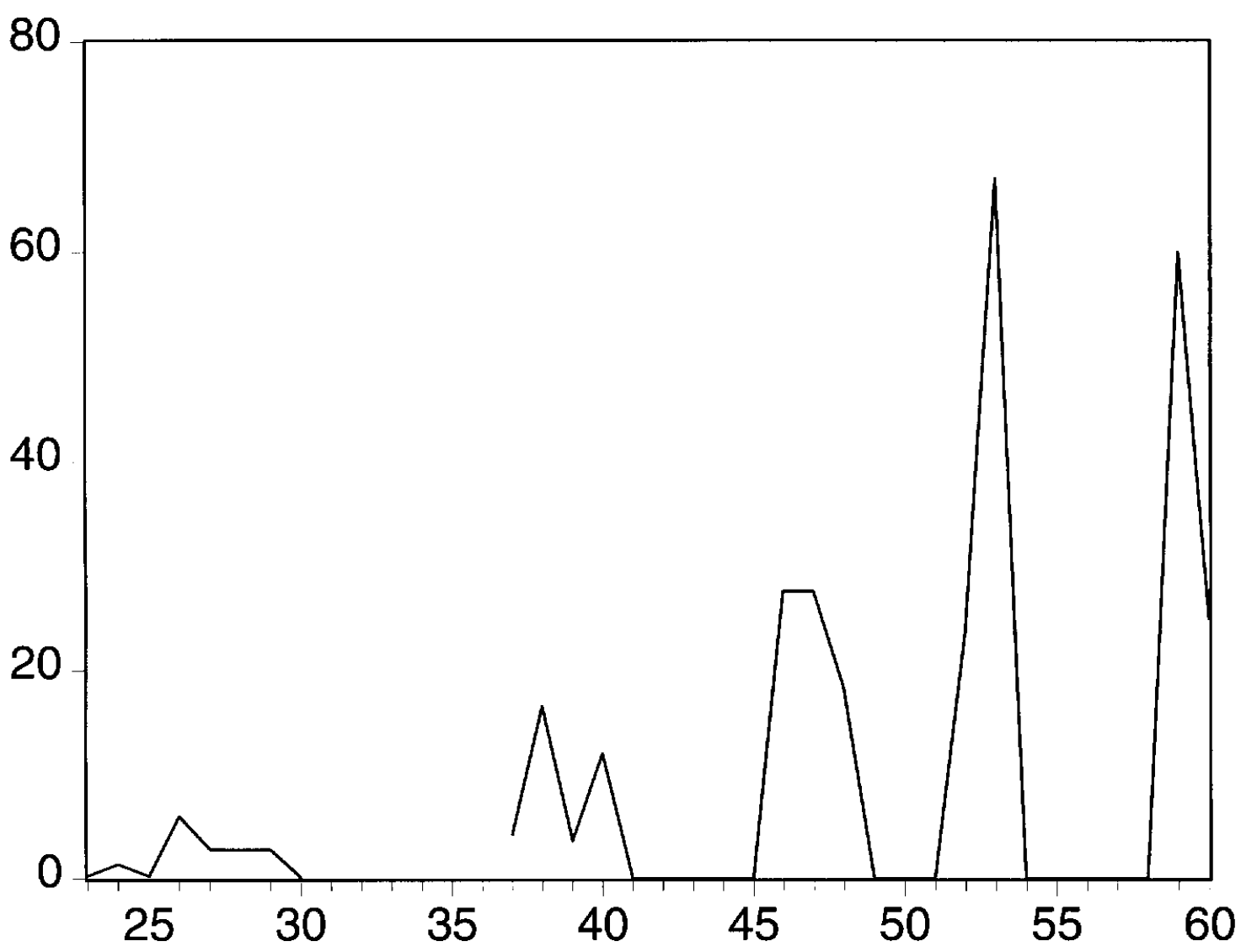

Source: Burgin (1946) and Cortes Conde (1989) 
Figure 4. Argentina: Fiscal accounts, 1810-1850

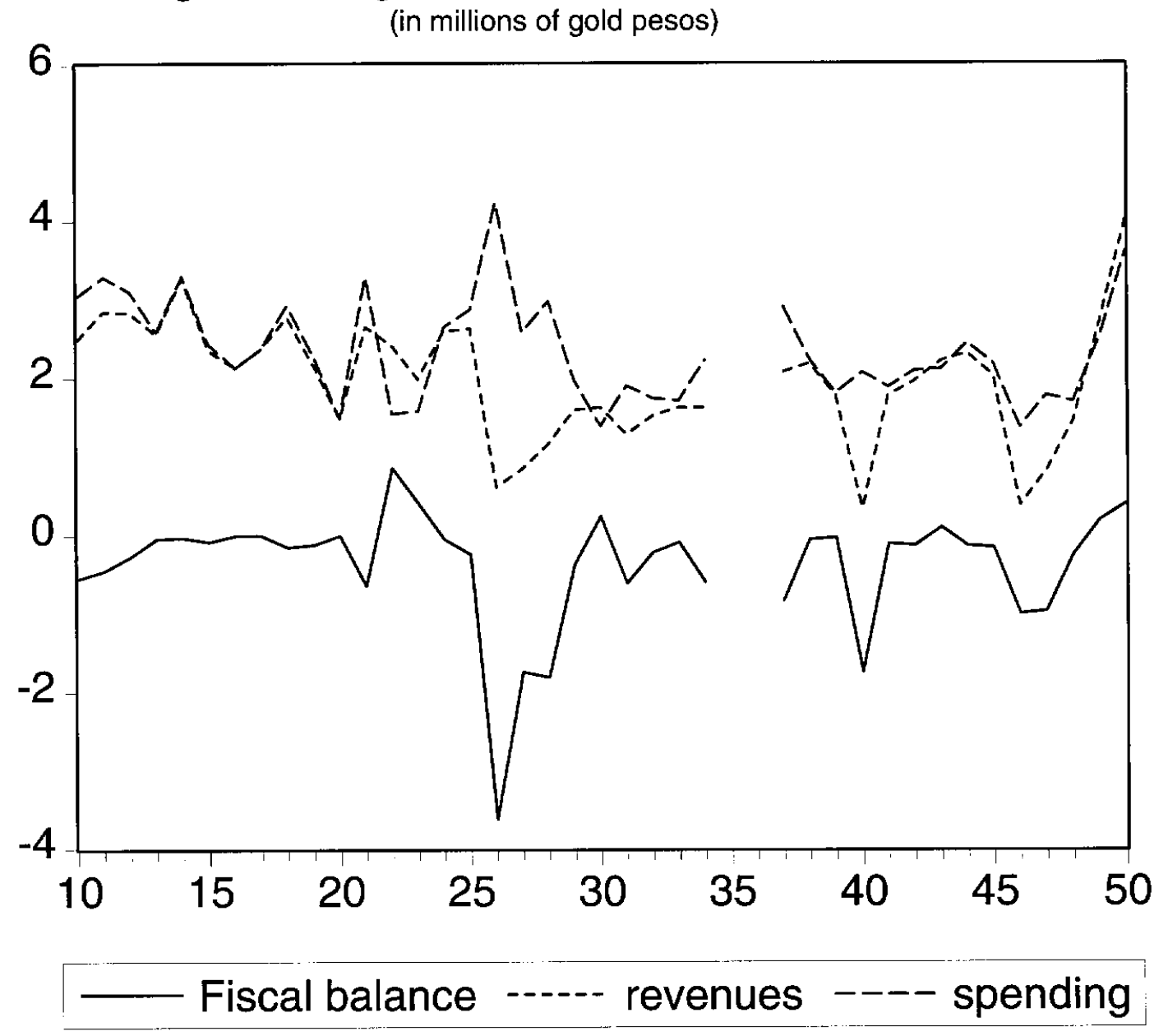

Source: Cortes Conde and McCandless (1997) 
Figure 5. United States: High-powered money, 1774-1900 (in millions of US\$)

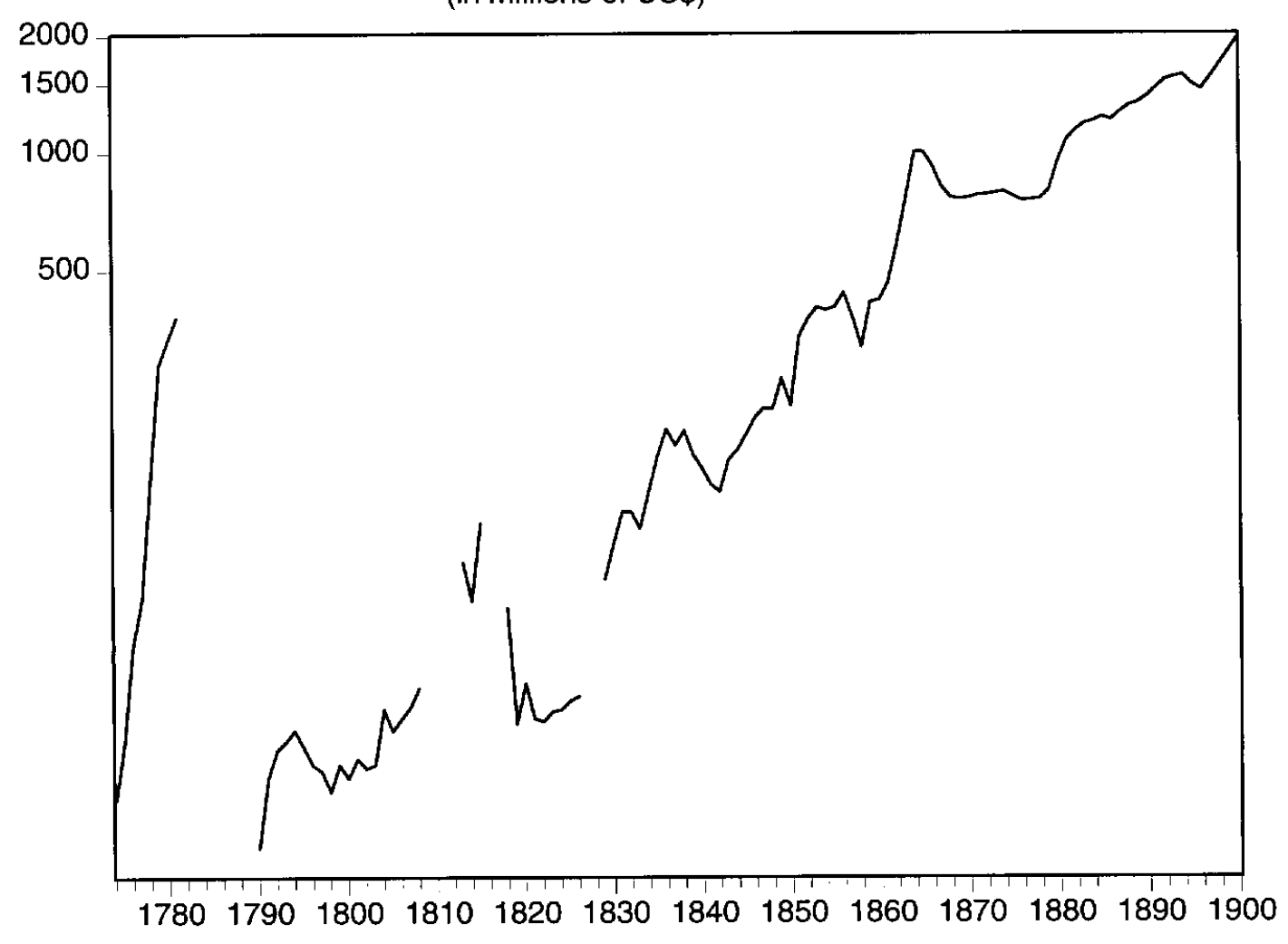

Source: Calomiris (1988) and Friedman and Schwartz (1970) 
Figure 6. United States: Consumer price index, 1774-1900

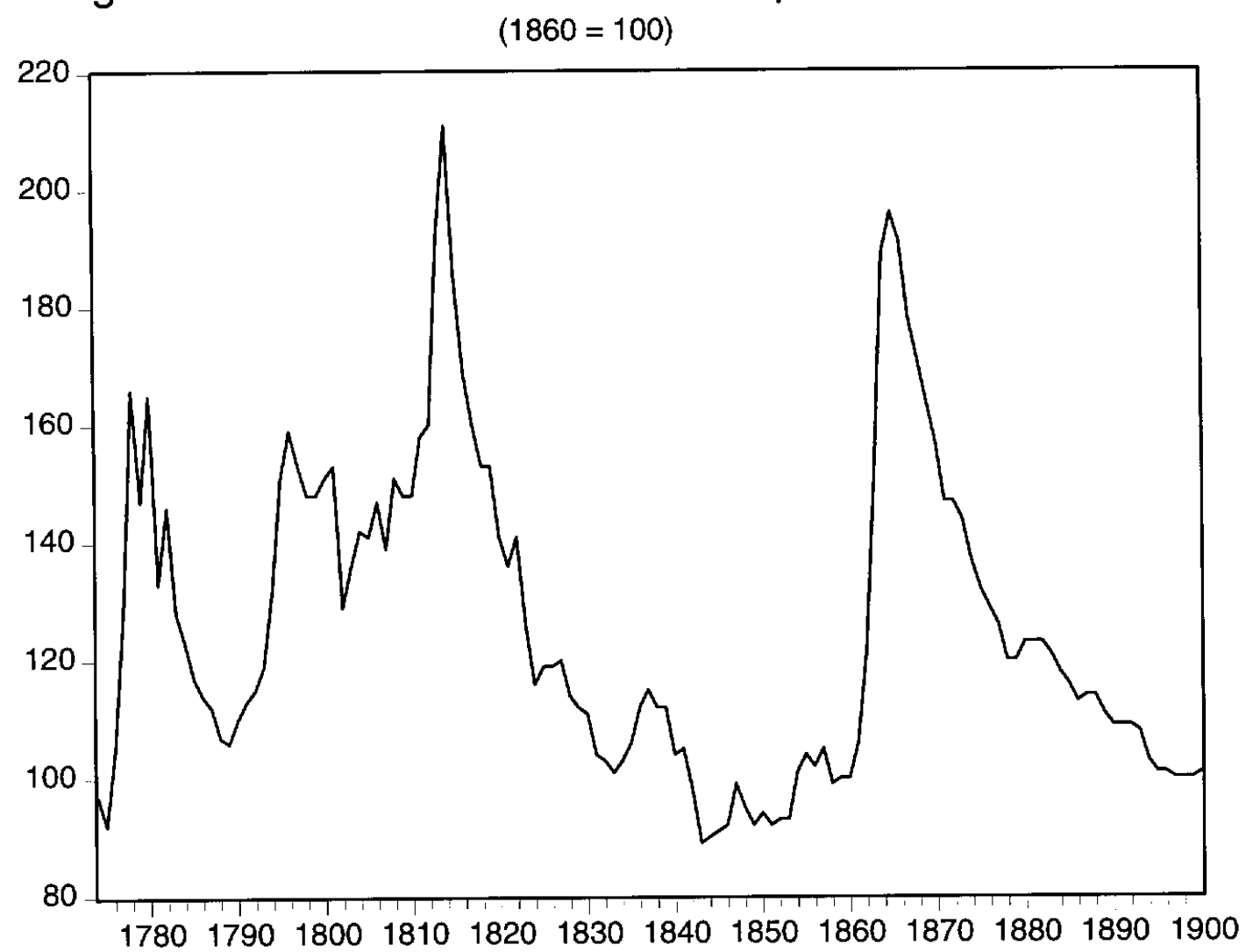

Source: David and Solar (1977) 
Figure 7. United States: Dollar/Pound exchange rate

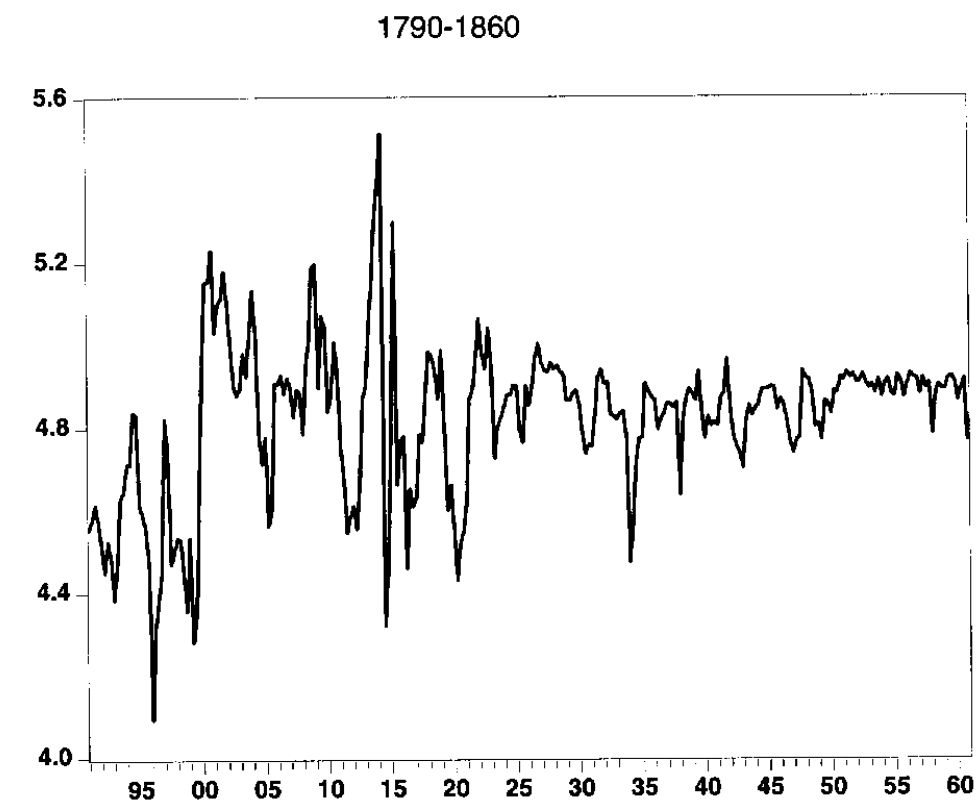

$1790-1900$

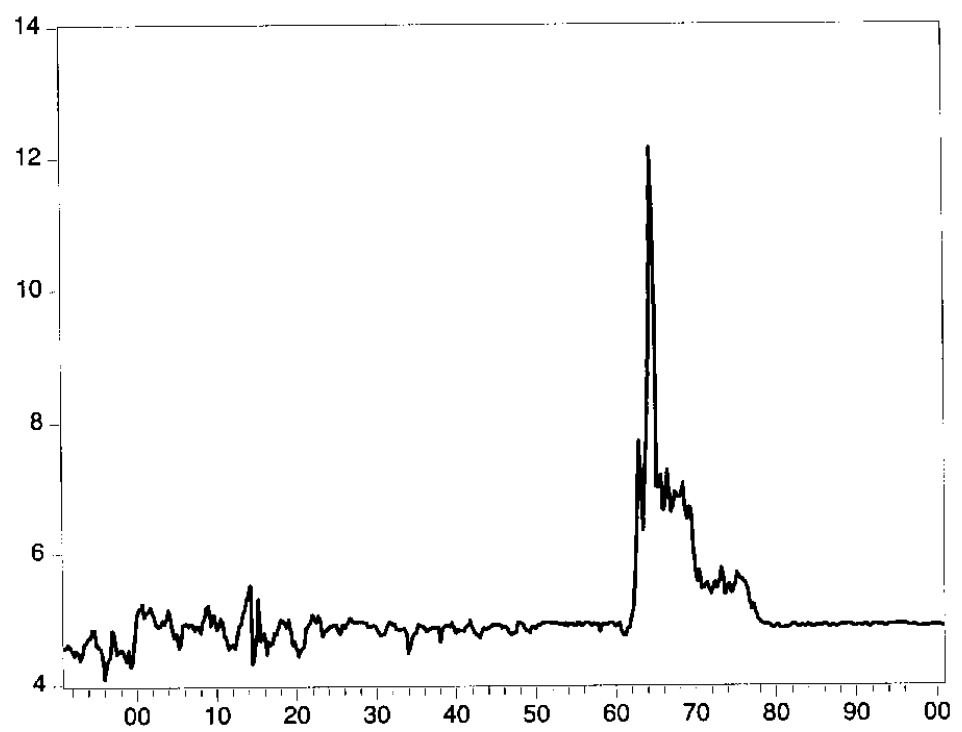

Source: Officer $(1983,1985)$ and Friedman and Schwartz (1982) 
Figure 8. United States: Public debt, 1790-1900

(in thousands of US\$)

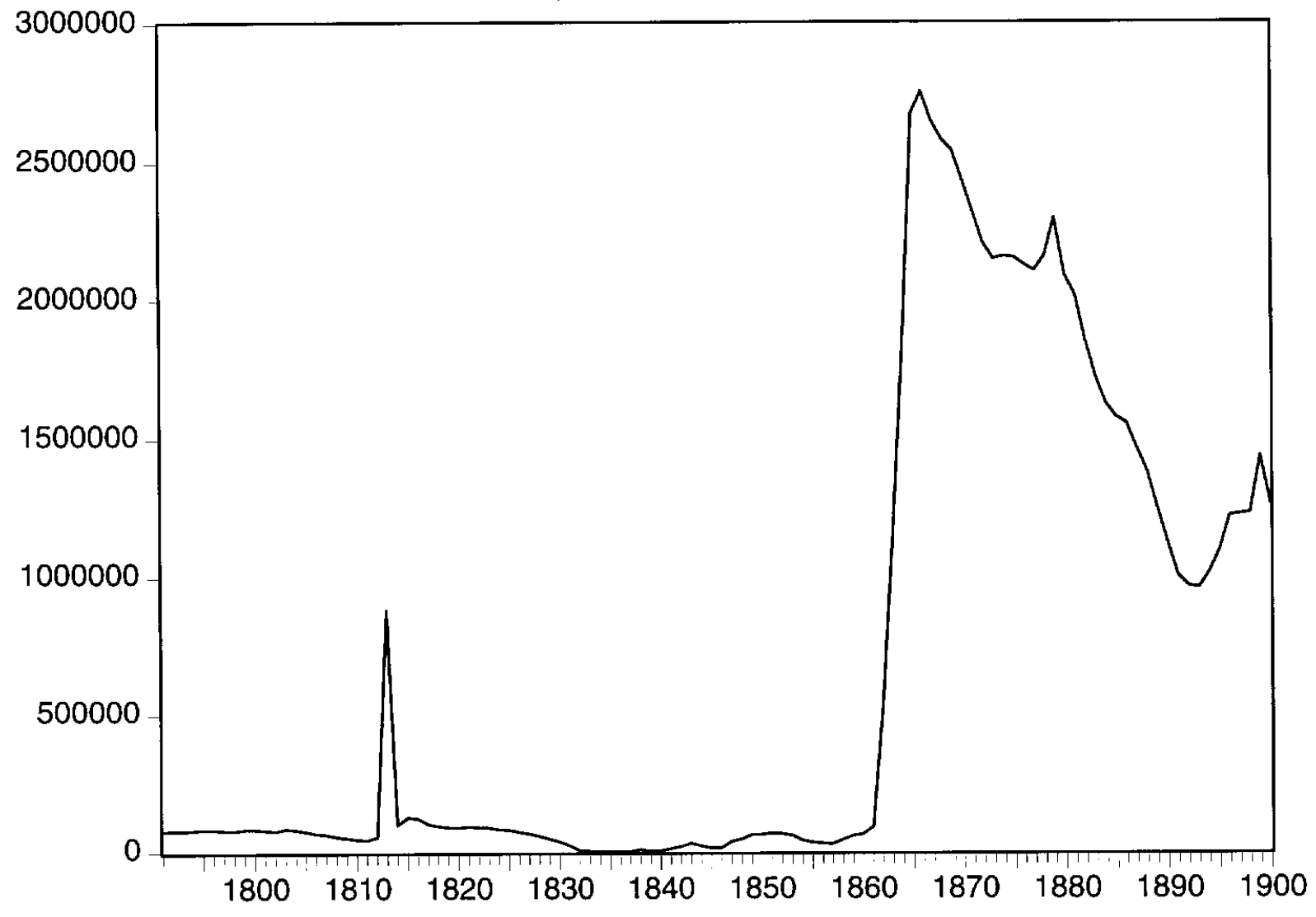

Source: Historical Statistics of the United States (1976) 
Figure 9. United States: Fiscal balance

(in thousands of US\$)

$1790-1860$

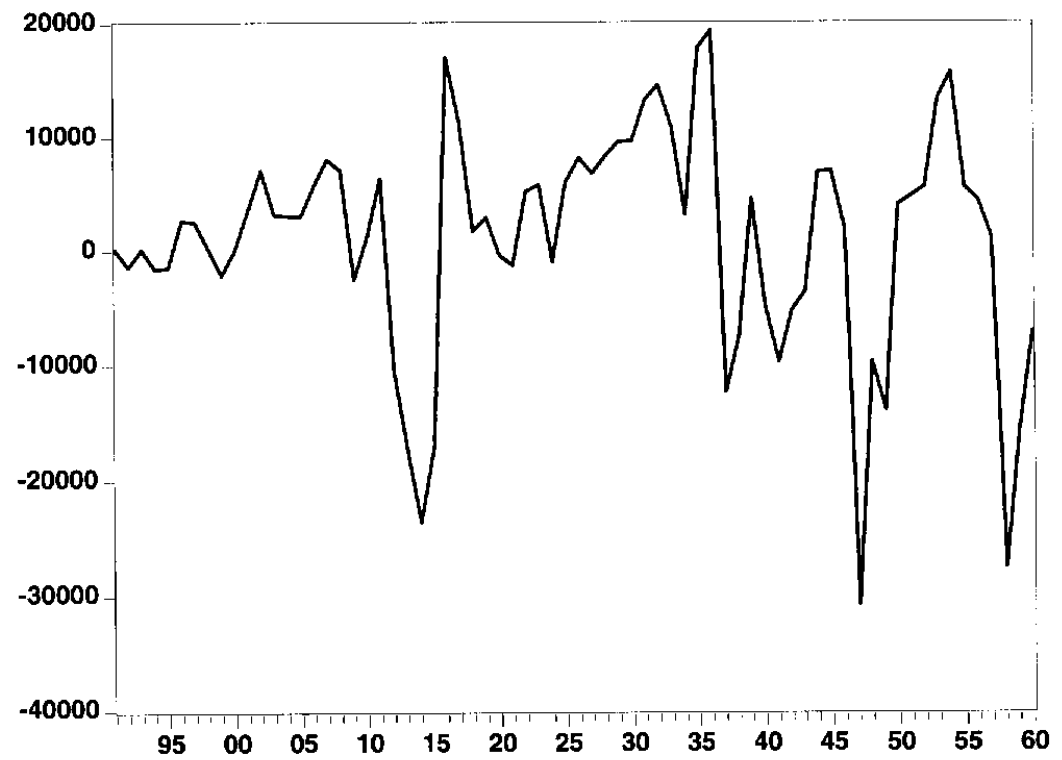

$1790-1900$

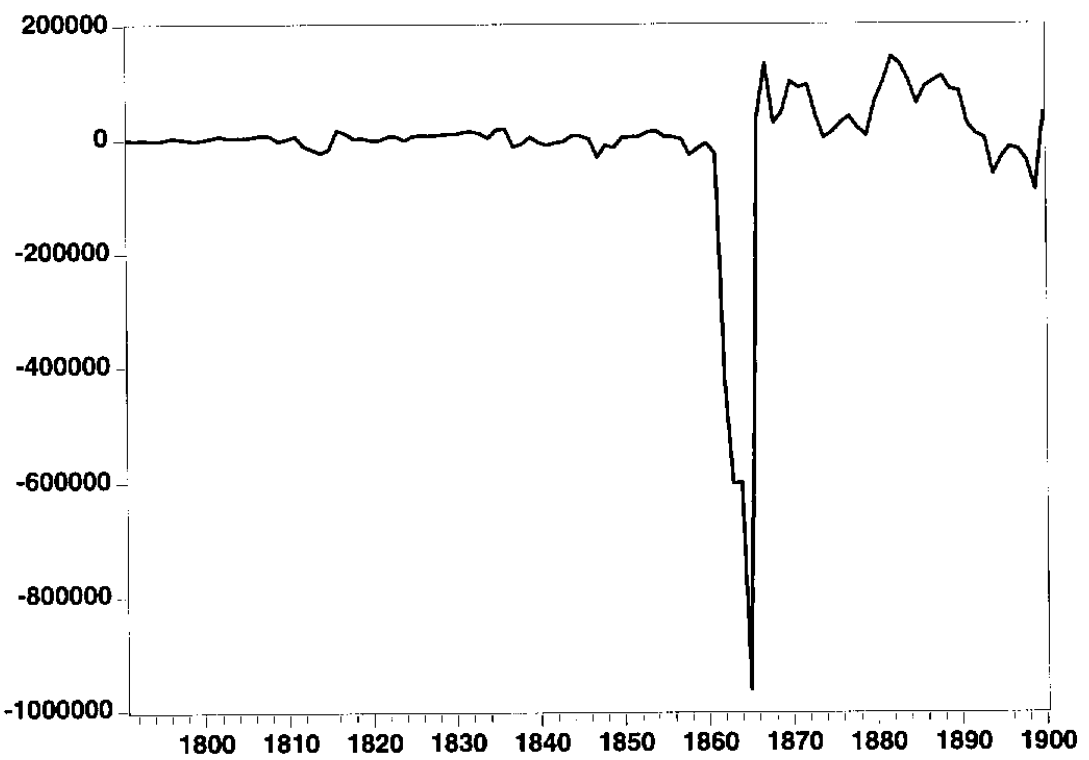

Source: Historical Statistics of the United States 
Figure 10. United States: Fiscal expenditures and revenues

(in thousands of US\$)

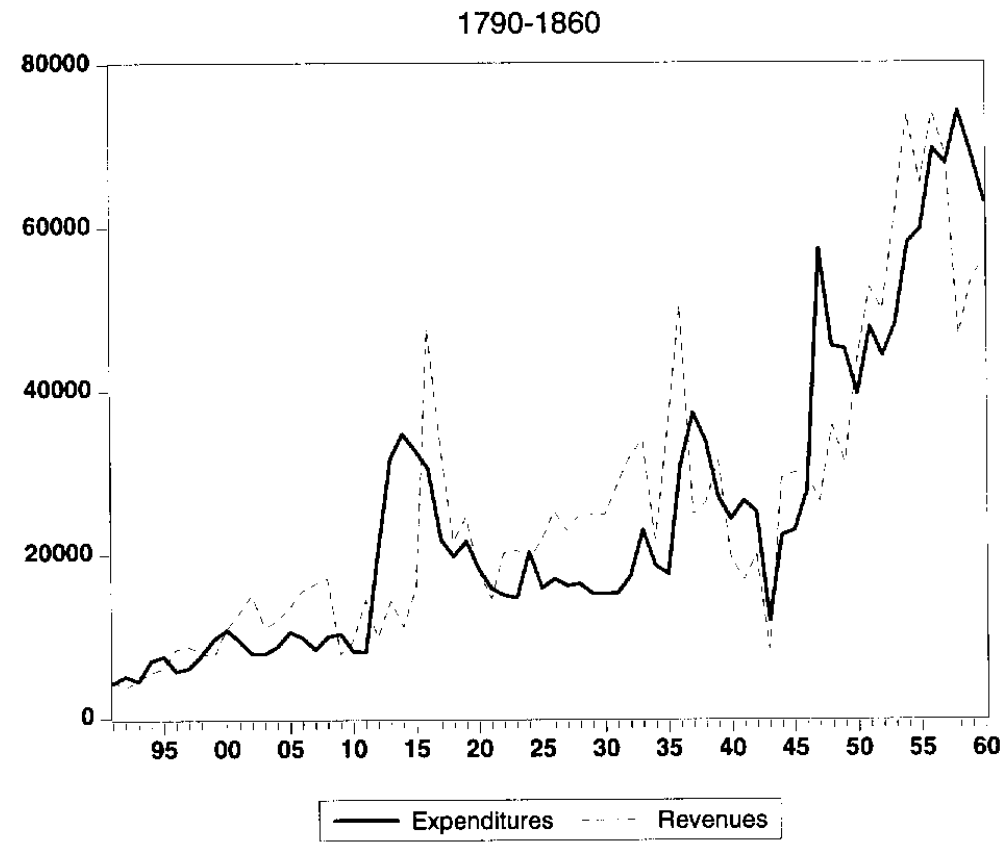

1790-1900

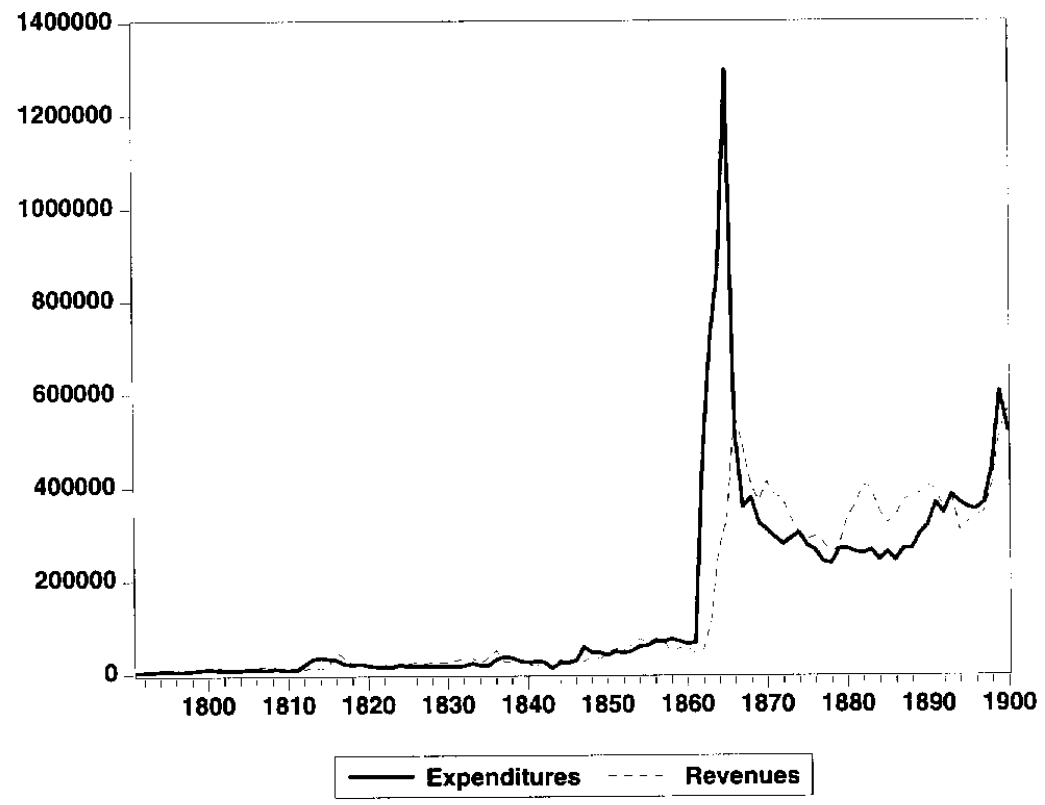

Source: Historical Statistics of the United States (1976) 
Figure 11. Time-varying collection costs
A. Government spending
B. Collection costs parameter
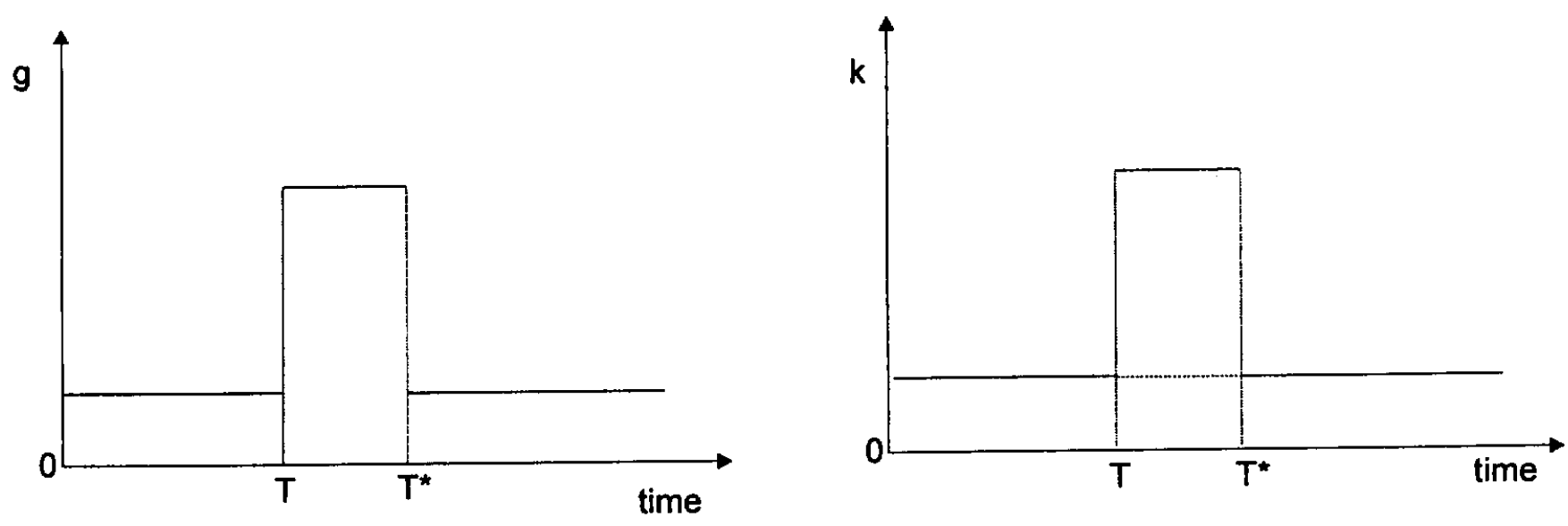

C. Consumption tax

D. Inflation tax
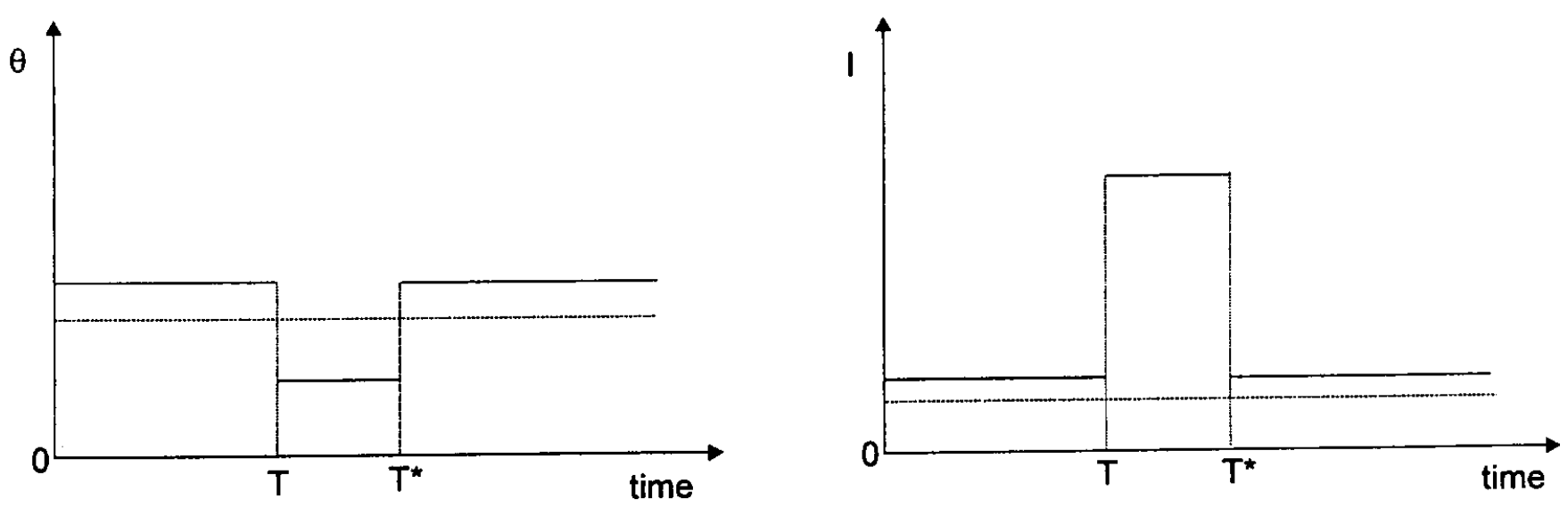
Figure 12. Costly borrowing

A. Government spending

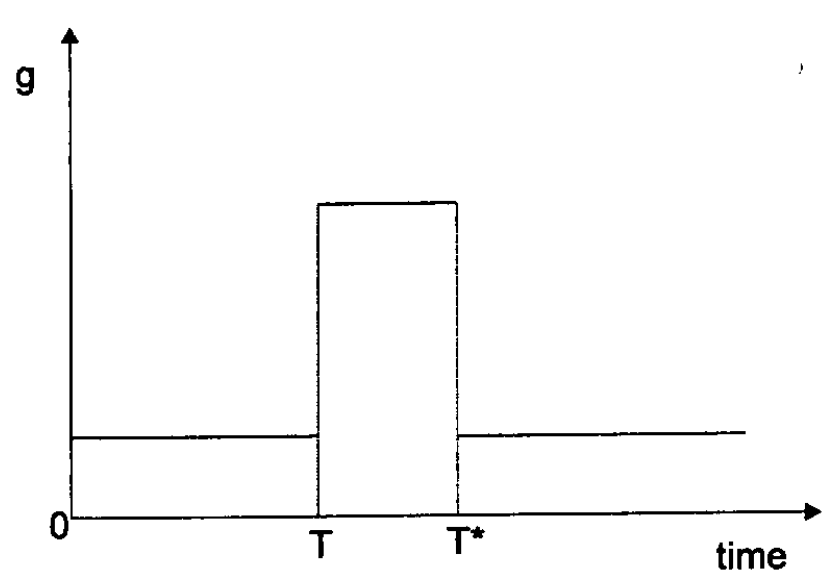

C. Consumption tax

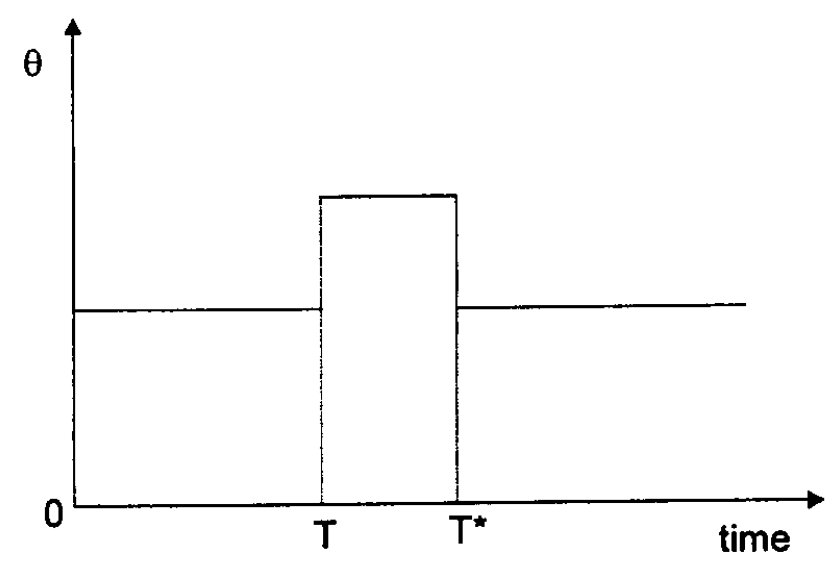

B. Collection costs parameter

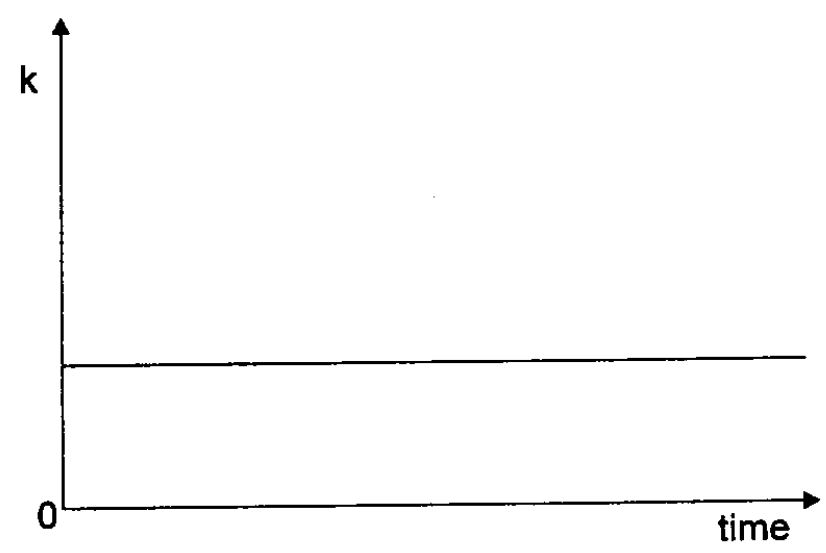

D. Inflation tax

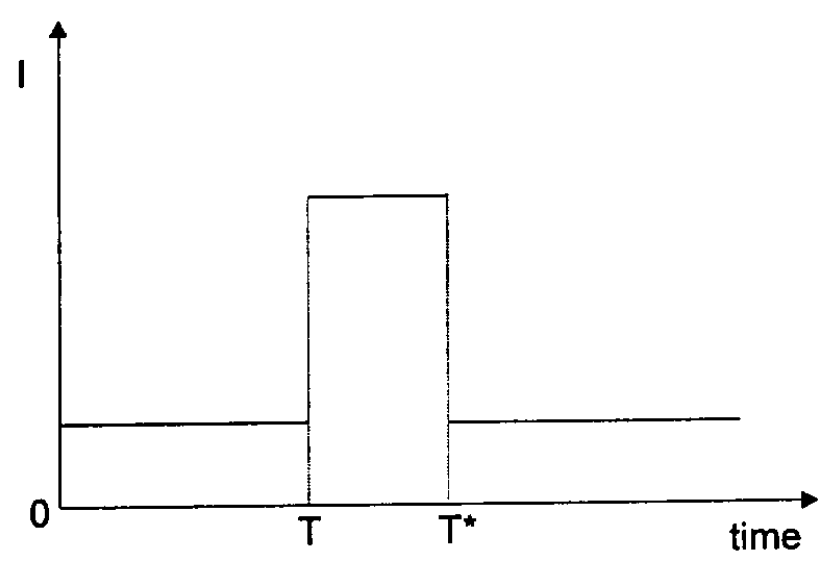


Figure 13. Non-costly unanticipated inflation

A. Government spending

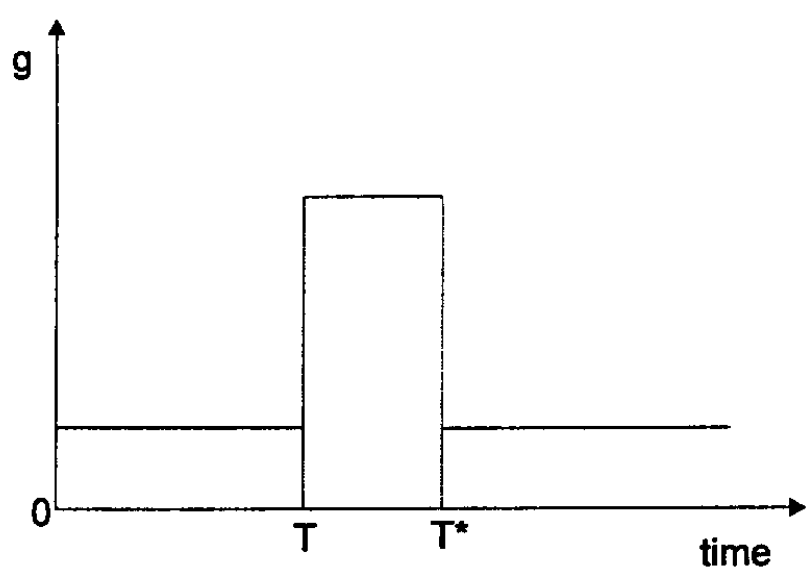

C. Consumption tax

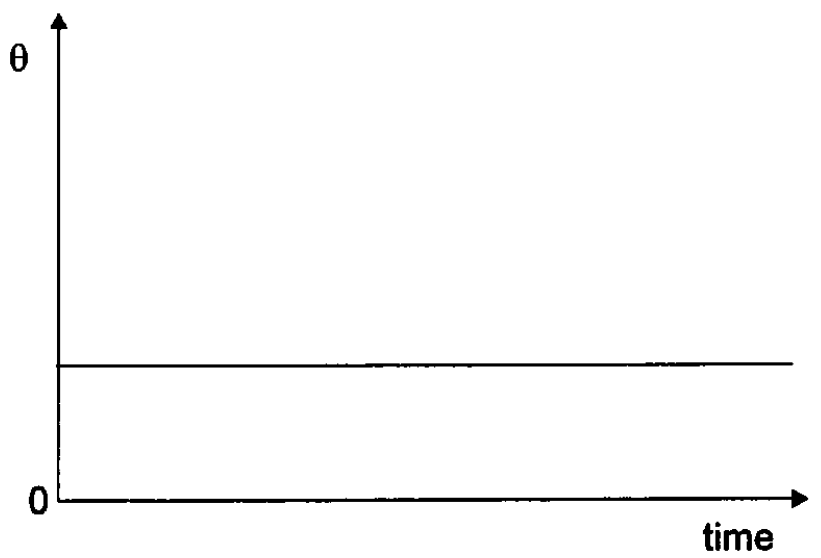

B. Collection costs parameter

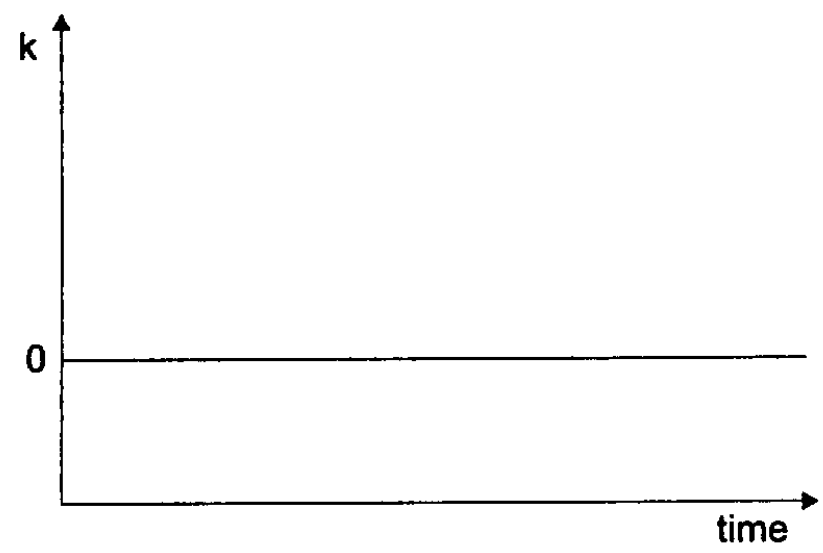

D. Inflation rate

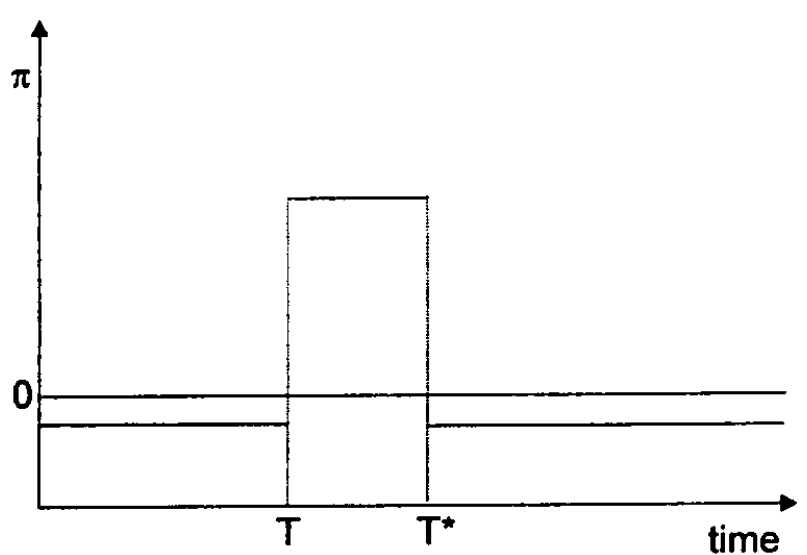

